\title{
Hormonally impregnated intrauterine systems (IUSs) versus other forms of reversible contraceptives as effective methods of preventing pregnancy (Unknown)
}

French R, Cowan F, Mansour D, Morris S, Hughes D, Robinson A, Proctor T, Summerbell C, Logan S, Guillebaud J

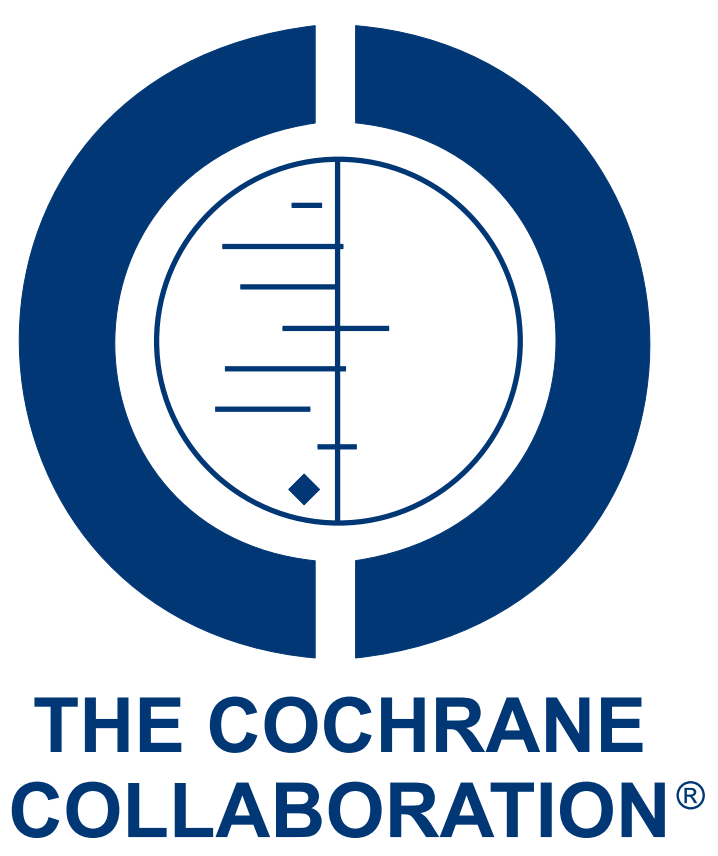

This is a reprint of a Cochrane unknown, prepared and maintained by The Cochrane Collaboration and published in The Cochrane Library 2000, Issue 1

http://www.thecochranelibrary.com

\section{WILEY}

Hormonally impregnated intrauterine systems (IUSs) versus other forms of reversible contraceptives as effective methods of preventing pregnancy (Unknown)

Copyright $\odot 2004$ The Cochrane Collaboration. Published by John Wiley \& Sons, Ltd. 
TABLE OF CONTENTS

ABSTRACT . . . . . . . . . . . . . . . . . . . . . . . . . . . . . . . . . . . . . . . . . . . . . . .

SYNOPSIS . . . . . . . . . . . . . . . . . . . . . . . . . . . . . . . . . . . . . . . 2

BACKGROUND . . . . . . . . . . . . . . . . . . . . . . . . . . . . . . . . . . . . . 2

OBJECTIVES . . . . . . . . . . . . . . . . . . . . . . . . . . . . . . . . . . . . . . . . . . . . . . 3

CRITERIA FOR CONSIDERING STUDIES FOR THIS REVIEW . . . . . . . . . . . . . . . . . . . . . . . . . 3

SEARCH STRATEGY FOR IDENTIFICATION OF STUDIES . . . . . . . . . . . . . . . . . . . . . . . . . . . 4

METHODS OF THE REVIEW . . . . . . . . . . . . . . . . . . . . . . . . . . . . . . . . . . . . . 4

DESCRIPTION OF STUDIES . . . . . . . . . . . . . . . . . . . . . . . . . . . . . . . . . . . . . . . . . . . . .

METHODOLOGICAL QUALITY . . . . . . . . . . . . . . . . . . . . . . . . . . . . . . . . . . . 6

RESULTS . . . . . . . . . . . . . . . . . . . . . . . . . . . . . . . . . . . 6

DISCUSSION . . . . . . . . . . . . . . . . . . . . . . . . . . . . . . . . . . . . . . . . . 8

REVIEWERS' CONCLUSIONS . . . . . . . . . . . . . . . . . . . . . . . . . . . . . . . . . . . . . . . $\quad 8$

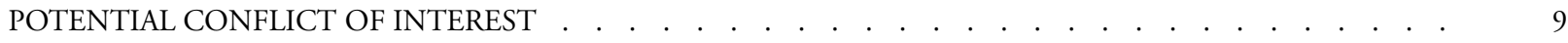

ACKNOWLEDGEMENTS . . . . . . . . . . . . . . . . . . . . . . . . . . . . . . . . . . . . . . . . . . . . 9.9

SOURCES OF SUPPORT . . . . . . . . . . . . . . . . . . . . . . . . . . . . . . . . . . . . . . . . 9

REFERENCES . . . . . . . . . . . . . . . . . . . . . . . . . . . . . . . . . . . . . . 9

TABLES . . . . . . . . . . . . . . . . . . . . . . . . . . . . . . . . . . . . . . . . . 12

Characteristics of included studies . . . . . . . . . . . . . . . . . . . . . . . . . . . . . . . . . .

Characteristics of excluded studies . . . . . . . . . . . . . . . . . . . . . . . . . . . . . . . . . . 19

Characteristics of ongoing studies . . . . . . . . . . . . . . . . . . . . . . . . . . . . . . . . . . . . . . . .

GRAPHS . . . . . . . . . . . . . . . . . . . . . . . . . . . . . . . . . . . . . . . $\quad 20$

Comparison 01. LNG-20 IUS vs. IUDs $>250 \mathrm{~mm} 2$. . . . . . . . . . . . . . . . . . . . . . . . . . . . . . . 20

Comparison 02. LNG-20 IUS vs. IUD<=250mm2 . . . . . . . . . . . . . . . . . . . . . . . . . . . . . . . 21

Comparison 03. LNG-20 IUS vs. Norplant-2 . . . . . . . . . . . . . . . . . . . . . . . . . . . . . . . . . 22

Comparison 04. Progestasert vs. IUDs $<=250 \mathrm{~mm} 2$.

Comparison 05. Progestasert vs. non-medicated IUD

COVER SHEET . . . . . . . . . . . . . . . . . . . . . . . . . . . . . . . . . . . . . 22

Comparison 05. Pregnancy due to method failure $\quad . \quad$. . . . . . . . . . . . . . . . . . . . . . . . . . . . . . 23

GRAPHS AND OTHER TABLES . . . . . . . . . . . . . . . . . . . . . . . . . . . . . . . . . . . . . 23

Comparison 05. Continuation of method . . . . . . . . . . . . . . . . . . . . . . . . . . . . . . . . . . . . . $\quad$. 24

Comparison 05. Planned pregnancy after discontinuation of method . . . . . . . . . . . . . . . . . . . 24

Comparison 05. Amenorrhoea . . . . . . . . . . . . . . . . . . . . . . . . . . . . . . . . . . . . 25

Comparison 05. Prolonged bleeding . . . . . . . . . . . . . . . . . . . . . . . . . . . . . . . . . . . . $\quad 25$

Comparison 05. Expulsion . . . . . . . . . . . . . . . . . . . . . . . . . . . . . . . . . . . . . . . . . $\quad .26$

Comparison 05. Embedded . . . . . . . . . . . . . . . . . . . . . . . . . . . . . . . . . 26

Comparison 05. Ectopic pregnancy . . . . . . . . . . . . . . . . . . . . . . . . . . . . . . . . . . . . . . 26

Comparison 05. Pelvic inflammatory disease . . . . . . . . . . . . . . . . . . . . . . . . . . . . . . . . . $\quad$. 27

Comparison 05. Hormonal reasons for discontinuation . . . . . . . . . . . . . . . . . . . . . . . . . . . . . 27

Comparison 05. Menstrual reasons for discontinuation: all c. . . . . . . . . . . . . . . . . . . . . . . . . $\quad$. 27

Comparison 05. Menstrual reasons for discontinuation: bleeding \& pain . . . . . . . . . . . . . . . . . . . . . . $\quad 28$

Comparison 05. Menstrual reasons for discontinuation: pain . . . . . . . . . . . . . . . . . . . . . . . . . . $\quad 28$

Comparison 05. Menstrual reasons for discontinuation: amenorrhoea . . . . . . . . . . . . . . . . . . . . . 28

Comparison 05. Discontinuation due to adverse event . . . . . . . . . . . . . . . . . . . . . . . . . . . . . . . 29

Comparison 05. Discontinuation because planning pregnancy $\quad . \quad$. . . . . . . . . . . . . . . . . . . . . . . . $\quad$. 29

Comparison 05. Personal reasons for discontinuation c. . . . . . . . . . . . . . . . . . . . . . . . . . . . $\quad 29$

Comparison 05. Pregnancy due to method failure $\quad . \quad$. . . . . . . . . . . . . . . . . . . . . . . . . . . . . . . $\quad 29$

Comparison 05. Continuation of method . . . . . . . . . . . . . . . . . . . . . . . . . . . . . . . . . 30

Comparison 05. Planned pregnancy after discontinuation of method . . . . . . . . . . . . . . . . . . . . . 31

Comparison 05. Headaches . . . . . . . . . . . . . . . . . . . . . . . . . . . . . . . . . . . . . . . . 31

Comparison 05. Breast tenderness . . . . . . . . . . . . . . . . . . . . . . . . . . . . . . . . . 32

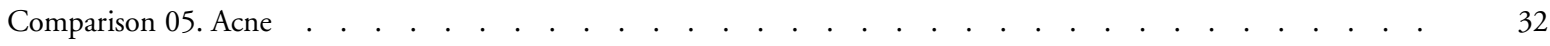

Hormonally impregnated intrauterine systems (IUSs) versus other forms of reversible contraceptives as effective methods of preventing pregnancy

Copyright $\odot 2004$ The Cochrane Collaboration. Published by John Wiley \& Sons, Ltd 
Comparison 05. Nausea

Comparison 05. Ovarian cysts . . . . . . . . . . . . . . . . . . . . . . . . . . . . . . . . . . . . . . . . . . . .

Comparison 05. Expulsion . . . . . . . . . . . . . . . . . . . . . . . . . . . . . . . . . . . . . . . . . .

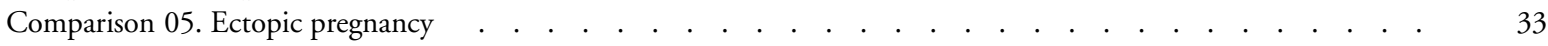

Comparison 05. Pelvic inflammatory disease . . . . . . . . . . . . . . . . . . . . . . . . . . . . . . . . . . 34

Comparison 05. Hormonal reasons for discontinuation . . . . . . . . . . . . . . . . . . . . . . . . . . 34

Comparison 05. Menstrual reasons for discontinuation: all c. . . . . . . . . . . . . . . . . . . . . . . . . . . $\quad 35$

Comparison 05. Menstrual reasons for discontinuation: bleeding \& pain . . . . . . . . . . . . . . . . . . . . . . 35

Comparison 05. Menstrual reasons for discontinuation: amenorrhoea . . . . . . . . . . . . . . . . . . . $\quad 35$

Comparison 05. Discontinuation due to adverse event.$\quad$. . . . . . . . . . . . . . . . . . . . . . . . . . . . . $\quad$. 35

Comparison 05. Discontinuation because planning pregnancy . . . . . . . . . . . . . . . . . . . . . . . . 36

Comparison 05. Discontinuation for personal reasons . . . . . . . . . . . . . . . . . . . . . . . . . . . . . . . . 36

Comparison 05. Pregnancy . . . . . . . . . . . . . . . . . . . . . . . . . . . . . . . . . . . . . . . . . .

Comparison 05. Continuation of method . . . . . . . . . . . . . . . . . . . . . . . . . . . . . . . . . . . $\quad$. 36

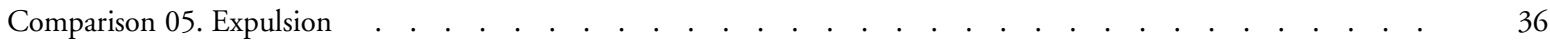

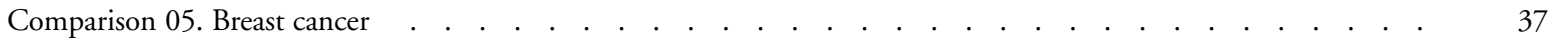

Comparison 05. Ovarian cysts . . . . . . . . . . . . . . . . . . . . . . . . . . . . . . . . . . . . . . . . . .

Comparison 05. Spotting . . . . . . . . . . . . . . . . . . . . . . . . . . . . . . . . . . . . . . .

Comparison 05. Oligomenorrhoea . . . . . . . . . . . . . . . . . . . . . . . . . . . . . . . . . . . . 38

Comparison 05. Amenorrhoea . . . . . . . . . . . . . . . . . . . . . . . . . . . . . . . . . . . . . .

Comparison 05. Prolonged bleeding . . . . . . . . . . . . . . . . . . . . . . . . . . . . . . . . . . . . . 40

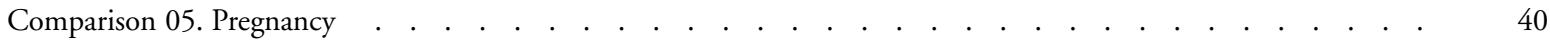

Comparison 05. Continuation of method . . . . . . . . . . . . . . . . . . . . . . . . . . . . . . . . . . . 40

Comparison 05. Expulsion . . . . . . . . . . . . . . . . . . . . . . . . . . . . . . . . . . . . . . . . 40

Comparison 05. Ectopic pregnancy . . . . . . . . . . . . . . . . . . . . . . . . . . . . . . . . . . . . . 41

Comparison 05. Menstrual reasons for discontinuation: bleeding \& pain . . . . . . . . . . . . . . . . . . . . . . 41

Comparison 05. Pregnancy . . . . . . . . . . . . . . . . . . . . . . . . . . . . . . . . . . . . . . . . . . . 41

Comparison 05. Continuation of method . . . . . . . . . . . . . . . . . . . . . . . . . . . . . . . . . . $\quad$. 41

Comparison 05. Expulsion . . . . . . . . . . . . . . . . . . . . . . . . . . . . . . . . . . . . . . . . . . . . 41

Comparison 05. Ectopic pregnancy . . . . . . . . . . . . . . . . . . . . . . . . . . . . . . . . . . . . . 41

Comparison 05. Menstrual reasons for discontinuation: all . . . . . . . . . . . . . . . . . . . . . . . 42

Comparison 05. Discontinuation because planning pregnancy . . . . . . . . . . . . . . . . . . . . . . . . 42

Comparison 05. Discontinuation for personal reasons . . . . . . . . . . . . . . . . . . . . . . . . . . . . . . $\quad 42$

Hormonally impregnated intrauterine systems (IUSs) versus other forms of reversible contraceptives as effective methods of preventing ii pregnancy

Copyright $\odot 2004$ The Cochrane Collaboration. Published by John Wiley \& Sons, Ltd 


\title{
Hormonally impregnated intrauterine systems (IUSs) versus other forms of reversible contraceptives as effective methods of preventing pregnancy
}

\author{
French R, Cowan F, Mansour D, Morris S, Hughes D, Robinson A, Proctor T, Summerbell C, \\ Logan S, Guillebaud J
}

\author{
This record should be cited as: \\ French R, Cowan F, Mansour D, Morris S, Hughes D, Robinson A, Proctor T, Summerbell C, Logan S, Guillebaud J. Hormonally \\ impregnated intrauterine systems (IUSs) versus other forms of reversible contraceptives as effective methods of preventing pregnancy. \\ The Cochrane Database of Systematic Reviews, Issue . Art. No.: CD001776. DOI: 10.1002/14651858.CD001776.
}

This version first published online: 24 January 2000 in Issue, .

Date of most recent substantive amendment: 11 November 1999

\begin{abstract}
A B S T R A C T
Background

In the 1970s a new approach to the delivery of hormonal contraception was researched and developed. It was suggested that the addition of a progestogen to a non-medicated contraceptive device improved its contraceptive action. An advantage of these hormonally impregnated intrauterine systems (IUS) is that they are relatively maintenance free, with users having to consciously discontinue using them to become pregnant rather than taking a proactive daily decision to avoid conception.
\end{abstract}

\section{Objectives}

To assess the contraceptive efficacy, tolerability and acceptability of hormonally impregnated intrauterine systems (IUSs) in comparison to other reversible contraceptive methods.

\section{Search strategy}

Literature was identified through database searches, reference lists and individuals/organisations working in the field. Searches covered the period from 1972 to July 1998.

\section{Selection criteria}

All randomised controlled trials comparing IUSs with other forms of reversible contraceptives and reporting on pre-determined outcomes in women of reproductive years. The primary outcomes were pregnancy due to method/user failure and continuation rate.

Data collection and analysis

The quality assessment of studies and data extraction were completed independently by two blinded reviewers. A quality checklist was designed to identify general methodological and contraceptive specific factors which could bias results. Events per women months and single decrement life table rates were extracted where possible for pregnancy, continuation, adverse events and reasons for discontinuation. Events per total number of women at follow up were collected for hormonal side effects and menstrual disturbance.

When appropriate, data were pooled at the same points of follow up to calculate rate ratios in order to determine the relative effectiveness of one method compared to another. For the single decrement life table rates, the rate differences were pooled to determine the absolute difference in effectiveness of one method compared to another. Interventions were only combined if the contraceptive methods were similar. Non-hormonal IUDs were divided into three categories for the purpose of comparison with IUSs: IUDs $>250 \mathrm{~mm} 2$ (i.e. CuT 380A IUD and CuT 380 Ag IUD), IUDs <=250mm2 (i.e. Nova-T, Multiload, CuT 200 and CuT 220 IUDs) and non-medicated IUDs.

Hormonally impregnated intrauterine systems (IUSs) versus other forms of reversible contraceptives as effective methods of preventing I pregnancy

Copyright $\odot 2004$ The Cochrane Collaboration. Published by John Wiley \& Sons, Ltd 


\section{Main results}

Nineteen RCTs comparing hormonally impregnated IUSs to a reversible contraceptive method met the inclusion criteria and it was possible to include eight of these in the meta-analyses, four comparing LNG-20 IUSs with non-hormonal IUDs, one comparing the LNG-20 IUS with Norplant-2 and three comparing Progestasert with non-hormonal IUDs.

No significant difference was observed between the pregnancy rates for the LNG-20 users and those for the IUD $>250 \mathrm{~mm} 2$ users. However, women using the LNG-20 IUS were significantly less likely to become pregnant than those using the IUD $<=250 \mathrm{~mm} 2$. Women using the LNG-20 IUS were more likely to experience amenorrhoea and device expulsion than women using IUDs $>250 \mathrm{~mm} 2$. LNG-20 users were significantly more likely than all the IUD users to discontinue because of hormonal side effects and menstrual disturbance, which on further breakdown of the data was due to amenorrhoea. When the LNG-20 IUS was compared to Norplant2, the LNG-20 users were significantly more likely to experience amenorrhoea and oligomenorrhoea, but significantly less likely to experience prolonged bleeding and spotting. No other significant differences were observed.

Progestasert users were significantly less likely to become pregnant and less likely to continue on the method than non-medicated IUD users after one year, but no significant difference was noted for these two outcomes when Progestasert users were compared to IUD $<=250 \mathrm{~mm} 2$ users. The only other significant differences found in the meta-analyses were that Progestasert users were less likely to expel the device and more likely to discontinue the method because of menstrual bleeding and pain than users of IUDs $<=250 \mathrm{~mm} 2$.

\section{Reviewers' conclusions}

Current evidence suggests LNG-20 IUS users are no more or less likely to have unwanted pregnancies than IUD $>250 \mathrm{~mm} 2$ and Norplant-2 users. The LNG-20 IUS was more effective in preventing either intrauterine or extrauterine pregnancies than IUDs $<=250 \mathrm{~mm} 2$. The contraceptive effectiveness of Progestasert was significantly better than non-medicated IUDs, but no difference was observed when compared to IUDs $<=250 \mathrm{~mm} 2$. Continuation of LNG-20 IUS use was similar to continuation of the non-hormonal IUDs and Norplant-2. Amenorrhoea was the main reason for the discontinuation for the LNG-20 IUS and women should be informed of this prior to starting this method.

\section{SY NOP S IS}

No difference found in pregnancy rates for women using either the LNG-20 intrauterine system (IUS) ot intra-uterine device (IUD) for contraception

Reversible methods of contraception include the use of a system or device placed inside the uterus. The IUD is a copper device inserted into the uterus to prevent pregnancy. The intrauterine system (IUS) contains hormones that will be gradually released and change the environment inside the uterus to provide effective contraception until removed.

The review of trials compared IUDs to IUSs and found there was no difference in the rate of unplanned pregnancies. The review found that amenorrhoea (no menstrual period) is more likely with IUS use and that IUD use is more likely to cause heavy menstrual bleeding and pain.

\section{B A C K G R O U N D}

In the 1970s a new approach to the delivery of hormonal contraception was researched and developed. It was suggested that the addition of a progestogen to a non-medicated contraceptive device improved its contraceptive action. An advantage of these hormonally impregnated intrauterine systems (IUS) is that they are relatively maintenance free, with users having to consciously discontinue using them to become pregnant rather than taking a proactive daily decision to avoid conception.

Progestasert

The first IUS to be marketed was Progestasert. It has a plastic T shaped frame with a $32 \mathrm{~mm}$ horizontal cross bar and a $36 \mathrm{~mm}$ vertical stem. The vertical stem holds $38 \mathrm{mg}$ of progesterone within a silicone base and when it is placed within the uterus will release $65 \mathrm{mcg}$ of progesterone per day. Its contraceptive action lasts for 12-18 months (Barnhart 1985) and is achieved by the endometrial suppression preventing implantation. A second mechanism involves the thickening of the cervical mucus preventing sperm penetration. Ovulation, however, is not affected with normal hormonal cyclical patterns demonstrated in users.

The license has been not renewed by the company in some countries in light of its reported disadvantages. These included:-

Hormonally impregnated intrauterine systems (IUSs) versus other forms of reversible contraceptives as effective methods of preventing 2 pregnancy 
- yearly reinsertions with the associated risk of pelvic inflammatory disease;

- increased ectopic pregnancy rate when compared to copper bearing devices;

- some women experiencing persistent menstrual spotting.

Levonorgestrel Intrauterine System

The levonorgestrel intrauterine system (LNG-IUS), Mirena, is licensed for contraceptive use in 25 countries (Schering 1999). It has a $\mathrm{T}$ shaped plastic frame $32 \mathrm{~mm}$ long with a reservoir on the vertical stem of the IUS containing $52 \mathrm{mg}$ of levonorgestrel mixed with polydimethylsiloxane. This allows a steady, local release of $20 \mu \mathrm{g}$ levonorgestrel per day. Insertion of the LNG-20 IUS may require local anaesthesia and dilatation of the cervical canal in nulliparous or peri-menopausal woman. The net ingredient cost of the LNG-20 IUS is more expensive than copper bearing IUDs, however it offers non-contraceptive benefits particularly in women with heavy periods and may offer an alternative to hysterectomy (Barrington 1997; Irvine 1998).

Measuring contraceptive effectiveness

Extensive reviews have helped to provide greater clarity in the understanding of the various methods and terminologies employed to measure contraceptive effectiveness and have examined their relative advantages and disadvantages (Trussell 1991; Farley 1986). In brief, there are generally two methods which have been adopted, the Pearl Index (PI) and life-tables. The PI, the older method (Pearl 1933), provides a rate per women years and is calculated by dividing the number of events (such as the number of women who discontinue using a contraceptive method) by the total number of women months and multiplying by 1200 (or 1300 if measurement is calculated by menstrual cycle). This method has been criticised because it does not account for the variation in risk of outcomes over time, nor does it account for the variation in loss to follow up (Potter 1966; Higgins 1985). Life tables do account for these factors and are therefore the most appropriate way to report contraceptive data. Confusion arises because inconsistent methods are used to define and calculate these probabilities. In brief, multipledecrement life table probabilities (also known as net, competing or crude rates) are calculated by working out the monthly probability of reasons for discontinuation, such as pregnancy or hormonal side effects, and multiplying these to establish the probability of discontinuation over a fixed period of time, i.e. at six months follow up, a year follow up, etc. However, single decrement life table probabilities (also known as gross, noncompeting or net rates) are recommended. They are calculated the same way but only for a single reason i.e. they censor women who discontinue a method for reasons other than the one being measured. Unfortunately, it is often impossible to distinguish which method has been used if it is not clearly stated by the authors as 'net' can be refering to single or multiple decrement probabilities.

\section{O B J E C T I VES}

To determine the effectiveness, acceptability and tolerability of IUSs. In order to do this the following questions were asked:

1. What is the relative effectiveness of IUSs in comparison to other reversible contraceptive methods?

2. What is the relative acceptability of IUSs in comparison to other reversible contraceptive methods?

3. What is the relative tolerability of IUSs in comparison to other reversible contraceptive methods?

4. What is the relative effectiveness of different types of IUS?

5. What is the relative acceptability of different types of IUS?

6. What is the relative tolerability of different types of IUS?

\section{CRITERIA FOR CONSIDERING STUDIES FOR THIS REVIEW}

\section{Types of studies}

All randomised controlled trial and controlled clinical (i.e. quasirandomised) trial comparisons of hormonally impregnated IUSs with other forms of reversible contraceptives.

\section{Types of participants}

women of reproductive years

\section{Types of intervention}

Hormonally impregnated IUSs versus:

non-hormonal IUDs

barrier contraceptives

oral contraceptives

injectable contraceptives

subdermal implants

Comparisons of different IUSs

\section{Types of outcome measures}

Primary outcome measures

Pregnancy due to method/user failure at 1,2, 3, 4 and 5 years after starting contraceptive method

Continuation of contraceptive method after 1, 2, 3, 4 and 5 years

Not enough evidence about hormonal contraceptive use during breastfeedingBreastfeeding provides some protection against another pregnancy, but the return of fertility is unpredictable. Which contraceptive method to use while breastfeeding, and when to start using it, are complicated decisions. Choices of contraception may be limited due to concerns about the effects of hormonal contraceptives such as the Pill on the quality and quantity of breastmilk, and the effects on the baby. The review found there is not enough evidence from trials to show the effects of hormonal contraceptives during breastfeeding.Secondary outcome measures

Planned pregnancy after discontinuation of contraceptive method at 1 and 2 years

Hormonally impregnated intrauterine systems (IUSs) versus other forms of reversible contraceptives as effective methods of preventing 3 pregnancy

Copyright @ 2004 The Cochrane Collaboration. Published by John Wiley \& Sons, Ltd 
Failed removal

Hormonal side effects:

Headaches

Pelvic pain

Breast tenderness

Acne

Weight gain

Nausea/vomiting

Dizziness/vertigo

Hair growth

Hair loss

Ovarian cysts

Uterine cramps

Mood changes

Loss of libido

Menstrual changes:

Dysmenorrhoea

Spotting

Oligomenorrhoea

Amenorrhoea

Menorrhagia

Prolonged bleeding

Irregular bleeding

Local device problems:

Malposition

Translocation

Expulsion

Adverse clinical events:

Ectopic pregnancy

Pelvic inflammatory disease

Sexually transmitted infections

Anaemia

Breast cancer

Fibroids

Vaginitis

Urinary tract infection

Cervical intraepithelial neoplasia I

Cervical intraepithelial neoplasia II

Cervical intraepithelial neoplasia III

Invasive cervical cancer

Myocardial infarction

Stroke

Pulmonary Embolism/thrombophlebitis

Gall bladder disease

Death

Reason for discontinuation:

Hormonal side effects

Menstrual disturbance

Adverse clinical event

Local device problem
Planning pregnancy

Patient choice - other

\section{SEARCH STRATEGY FOR IDENTIFICATIONOF STUDIES}

See: search strategy

The following search strategy was used:

\#1 “INTRAUTERINE-DEVICES,-MEDICATED” / all

subheadings

\#2 INTRAUTERINE SYSTEM* ${ }^{*}$ or IUS*

\#3 explode "NORGESTREL" / all subheadings

\#4 "LEVONORGESTREL"/all subheadings

\#5 NORGESTREL

\#6 LEVONORGESTREL

\#7 KETO near DESOGESTREL

\#8 ETONORGESTREL

\#9 PROGESTASERT

\#10 MIRENA

\#11 LEVONOVA

$\# 12 \# 1$ or $\# 2$ or $\# 3$ or $\# 4$ or $\# 5$ or $\# 6$ or $\# 7$ or $\# 8$ or $\# 9$ or $\# 10$ or $\# 11$

Computerised databases The Cochrane Controlled Trials Register, MEDLINE, EMBASE, POPLINE, the Science Citation Index and Psych. Lit. were searched (from 1972 to July, 1998) to identify publications describing randomised and controlled clinical trials of IUSs. The reference lists of all identified publications were searched for previously unidentified articles.

The relevant pharmaceutical companies were contacted and asked to release results of any relevant unpublished studies for inclusion in the review. Individuals and organisations with an interest in IUS research were contacted to identify unpublished and ongoing studies relevant to the review.

\section{METHODS OF THE REVIEW}

The selection of studies for inclusion and their methodological quality were independently assessed and reported by reviewers (RF and FC). Quality assessment forms were designed, and included general methodological factors, as well as some of contraceptive specific factors recommended by Trussell 1991.The following quality factors were included on the checklist:

- method of randomisation described,

- allocation concealment,

- blinded assessment of outcomes,

- groups treated identically other than named intervention,

- description of women who withdrew or were lost to follow up provided,

Hormonally impregnated intrauterine systems (IUSs) versus other forms of reversible contraceptives as effective methods of preventing pregnancy

Copyright ( 2004 The Cochrane Collaboration. Published by John Wiley \& Sons, Ltd 
- description of hormonal contraceptive method or pregnancy immediately prior to study enrolment,

- statistical method (with reference) used to analyse pregnancy and continuation of methods,

- description of contraceptive failure provided (i.e. user or method failure or both),

- active follow up conducted (i.e. analysis of follow up delayed a few months to allow inclusion of undetected pregnancies)

Single-decrement life table probabilities with their standard errors (SEs), and events per women months, akin to the Pearl Index rate, were collected for each outcome at specific follow up points (at one, two, three, four and five years). It was decided to collect both ways of reporting event rates as, although single-decrement rates are the ideal, they are not commonly employed and there was usually sufficient information in the papers to collect events per women months. Of those papers which had reported single decrement probabilities, only a few had given SEs, a necessity for metaanalysis. Authors who had used single decrement probabilities but had not given their SEs were contacted and asked to provide them where possible. Unless otherwise stated, in the rest of the text life table probabilities refers to single decrement life tables for any discontinuation outcomes.

Menstrual disturbance outcomes were only collected if investigators had stipulated that they had been measured over 90 day intervals as recommended by Rodriguez 1976. Number of events and total number of women at each 90 day interval were collected to calculate risk ratios for menstrual disturbance outcomes.

Data on hormonal side effects and planned pregnancy (after discontinuation of contraceptive method) were collected at yearly time intervals. Data on these outcomes were only collected if the investigators provided number of events and total number of women at follow up, so that risk ratios for each of the side effects identified in the protocol could be determined. Data on weight change were collected by extracting the mean weight difference, with its standard deviation, between the contraceptive methods under investigation.

A description of the demographic characteristics of the study participants, the interventions, environmental and geographical factors which may influence findings, quality and the measured outcomes were collected, so that a decision could be made about the results of individual studies and whether it was feasible to combine the data.

Studies were only combined when the comparative interventions were similar, such as IUSs versus subdermal implants or IUSs versus non-hormonal IUDs contraceptives. Non-hormonal IUDs were divided into three categories for the purpose of data synthesis. The first, defined as IUDs $>250 \mathrm{~mm} 2$, included CuT $380 \mathrm{~A}$ and CuT 380Ag IUDs; the second, defined as IUDs $<=250 \mathrm{~mm} 2$, included the Nova-T, Multiload, CuT 200 and CuT 220 IUDs; and the third were non-medicated IUDs. The first two categories were based on the surface area of the copper wire. In situations where it was not possible or appropriate to synthesise data, a narrative description is provided.

In order to obtain a summary effect size of an event per women months the rate ratios of the case and control events were combined. This method gave a relative measure of 'treatment' effect, that is how much more or less likely IUS users experienced an event in comparison to users of other contraceptive methods. The log rate ratios and their variances for events were calculated for each study (Hasselblad 1995). It was then possible to calculate the inverse weighted average of the log rate ratios. Events were only combined if they were measured over the same time period (i.e. one year, two years and so on) because of their variability over time. For the purpose of data synthesis, in situations where there were no events in one arm of the trial a continuity correction was implemented by adding a half to each cell.

In order to synthesis life table probabilities, it was necessary to calculate the absolute measurement of 'treatment' effect. This was done by subtracting the control group probability from the intervention group probability. The SE for the measurement of true effect was then calculated by obtaining the square root of sum of the squared SE of the intervention group probability and the squared SE of the control group probability. If there was a probability of zero in one of the groups, its SE was assumed to be the same as the SE of the probability in the comparison group. The inverse weighted average of the rate differences was then calculated. It was thus possible to obtain an absolute difference in percentage terms of 'treatment' effect, that is the attributable risk, between IUS users and users of other contraceptive methods.

To order to obtain pooled estimates for risk ratios and mean differences, the inverse variance weighted average was used with the sample log risk ratio and the sample mean difference, respectively, calculated from each study (Petitti 1994). A continuity correction was performed when necessary as described above for the calculated rate ratios.

Microsoft Excel was used to calculate the pooled effect sizes as it was not possible to calculate rate ratios or life table differences in RevMan.

The degree of heterogeneity was investigated and reported. A random effects approach was used for the meta-analysis (Dersimonian 1986). In the absence of heterogeneity this coincides with a fixed effect analysis. No statistical heterogeneity was identified in the analyses unless explicitly stated in the results below.

An economic evaluation was conducted using the results of the systematic review and meta-analysis, and this has been published elsewhere (French 2000) 


\section{DESCRIPTIONOF STUDIES}

Nineteen RCTs, identified from 38 publications, comparing hormonally impregnated IUSs to a reversible contraceptive method met the inclusion criteria (See Table of Included Studies). Seven trials were conducted in developing or transitional countries (Affandi 1980; Andrade 1988; Baveja 1989; el Mahgoub 1982; Lavin 1983; Piazarro 1979; Wang 1992) six in developed countries (Andersson 1994; Fylling 1979; Heikkila 1982; Larsen 1981; Pakarinen 1996; Rybo 1983) and five were international multicentre studies conducted in both developed and developing countries (Luukkainen 1986; Sivin 1994; WHO 1983; WHO 1987; WHO 1997). In one publication it was not possible to determine the study setting (Newton 1979). The majority of trials (10) were set in community-based family planning clinics.

The age range of participants varied from $15-44$ years. None of the studies confined entry to specific age requirements, other than ensuring the recruited women were of reproductive age. Thirteen of the 19 trials limited recruitment to women with proven fertility (Andersson 1994; Andrade 1988; Baveja 1989; Heikkila 1982; Lavin 1983; Luukkainen 1986; Piazarro 1979; Rybo 1983; Sivin 1994; WHO 1987; Wang 1992; el Mahgoub 1982). Three studies recruited women immediately post partum or post abortion (Heikkila 1982; Lavin 1983; el Mahgoub 1982). One study restricted recruitment to women who were breast feeding (Heikkila 1982). Three studies stated that they only included women with regular menstrual cycles (Baveja 1989; Pakarinen 1996; Piazarro 1979).

Nearly all of the interventions were either comparisons of IUSs with different hormonal release rates or of IUSs versus nonhormonal IUDs. The one exception was a comparison of LNG-20 IUS with Norplant-2 (Wang 1992).

It was documented in two of the 19 trials that contraceptive counselling had been provided (Andersson 1994; Wang 1992). None of the studies mentioned any specific training for those inserting the devices.

\section{METHODOLOGICAL QUALITY}

Details of the methodological quality of each of the studies are provided in the Characteristics of Included Studies Table. It was documented that allocation of contraceptive method was concealed to the investigator in eight trials (Andersson 1994; Baveja 1989; Newton 1979; Pakarinen 1996; Sivin 1994; Wang 1992; WHO 1997; WHO 1983). It was reported that investigators were blind to contraceptive method when assessing outcomes in only three of the trials (Luukkainen 1986; Newton 1979; Piazarro 1979). Women were blind to allocated method in an additional two studies (Andersson 1994; Larsen 1981).
In 14 studies, the compared groups were treated identically in terms of measurement of outcomes (Andersson 1994; Baveja 1989; Fylling 1979; Larsen 1981; Lavin 1983; Luukkainen 1986; Newton 1979; Pakarinen 1996; Piazarro 1979; Rybo 1983; Sivin 1994; Wang 1992; WHO 1983; WHO 1987). A description of the characteristics of women lost to follow up or who withdrew from the study was not provided in any of the publications.

Twelve studies used life table analysis to determine pregnancy and continuation rates (Andersson 1994; Baveja 1989; el Mahgoub 1982; Larsen 1981; Luukkainen 1986; Newton 1979; Pakarinen 1996; Piazarro 1979; Sivin 1994; Wang 1992; WHO 1983; WHO 1987). It was possible to determine whether single or multiple decrement probabilities had been reported in nine of these studies (Andersson 1994; Baveja 1989; Larsen 1981; Luukkainen 1986; Pakarinen 1996; Sivin 1994; Wang 1992; WHO 1983; WHO 1987 ) and all but one provided single decrement probabilities (Larsen 1981).

Less than half of all studies provided information of contraceptive methods used (or pregnancy) immediately prior to enrolment (Andersson 1994; Andrade 1988; el Mahgoub 1982; Heikkila 1982; Lavin 1983; Luukkainen 1986; Piazarro 1979; Wang 1992). In the 15 studies where pregnancy occurred, nine distinguished between user or method failure (or both) (Andersson 1994; Baveja 1989; Luukkainen 1986; Pakarinen 1996; Piazarro 1979; Sivin 1994; Wang 1992; WHO 1983; WHO 1987). Active follow up was conducted in three trials (Sivin 1994; WHO 1983; WHO 1987).

\section{R E S U L T S}

Some studies which would have met the inclusion criteria but examined prototype contraceptive methods or methods that are not longer available were excluded from the meta-analyses (el Mahgoub 1982; Heikkila 1982; Pakarinen 1996; WHO 1983; WHO 1987).

Three studies compared the LNG-20 IUS with the non-hormonal IUD >250mm2 (Baveja 1989; Sivin 1994; WHO 1997). It was possible to extract data from two of these studies (Baveja 1989; Sivin 1994). The other study was still in progress at the time of this review. Rate ratios and single decrement life table differences derived from the two studies are presented in Table 01 and Table 02, respectively (for the following outcomes: pregnancy, continuation, expulsion, embedded device, ectopic pregnancy, PID, and discontiniation due to hormonal side effects, menstrual side effects, adverse events, planning a pregnancy and/or personal choice). The relative risk for planned pregnancy after removal of the LNG-20 IUS compared to CuT $380 \mathrm{Ag}$ IUD was 1.05 (95\% CI 0.83 to 1.33) at one year (Sivin 1994). It was possible to extract data on menstrual disturbance outcomes from one study only (Sivin 1994). Data from this study indicated that women using LNG-20

Hormonally impregnated intrauterine systems (IUSs) versus other forms of reversible contraceptives as effective methods of preventing 6 pregnancy

Copyright @ 2004 The Cochrane Collaboration. Published by John Wiley \& Sons, Ltd 
IUSs were more likely to experience amenorrhoea than women using CuT 380Ag IUDs and this risk increased over time, at three months the risk ratio was 2.25 [95\% CI 1.36 to 3.56] which increased to 7.24 [95\% CI $4.14-12.55]$ at three years follow up. No significant differences were noticed between LNG-20 IUS and CuT 380Ag IUDs in terms of prolonged bleeding, with risk ratios of 0.90 [95\% CI 0.62 to 1.30$]$ at three months and 0.1 [95\% CI 0.01 to 2.06 ] at three years. It was not possible to extract data for any other menstrual disturbance outcomes, but Sivin et al (1994) reported that LNG-20 IUS users were significantly less likely to experience dysmenorrhoea. No data were collected for hormonal side effects.

Three included studies compared the LNG-20 IUS with nonhormonal <=250mm2 IUDs (Andersson 1994; Baveja 1989; Luukkainen 1986). Data could be extracted from each of these studies. The calculated rate ratios and single decrement life table differences are shown in Table 03 and Table 04, respectively, for the following outcomes: unplanned pregnancy, continuation of method, adverse event outcomes and reasons for discontinuation. Unpublished data on discontinuation of the LNG-20 IUS compared to the Nova-T because of amenorrhoea from Andersson 1994 (provided by Leiras Ltd 1999) demonstrated a huge variation between the participating centres, ranging from a multiple decrement probability of $2.7 \%$ in Finland to $19.6 \%$ in Hungary. No significant differences were observed in the rate ratios for planned pregnancy after discontinuation of the LNG-20 IUS and the Nova-T IUD (Andersson 1994). The rate ratios at one and two years were 1.07 (95\% CI 0.88 to 1.32 ) and 1.07 (95\% CI 0.9 to $1.28)$, respectively. It was not possible to extract any data on menstrual disturbance outcomes that did not result in discontinuation. The Andersson 1994 study was the only one where it was possible to extract any data on hormonal side effects. No significant differences were observed between the risk of hormonal side effects for women using the LNG-20 IUS compared to women using the Nova-T IUD. These data were collected at five year follow up. The reported side effects and their risk ratios were as follows: acne, 5.56 [95\% CI 0.73 to 42.35]; headaches, 1.71 [95\% CI 0.49 to 6.02 ]; breast tenderness, 1.50 [95\% CI 0.31 to 7.17 ; ovarian cysts 1.50 [95\% CI 0.51 to 4.40 ] and nausea, 4.99 [95\% CI 0.24 to 103.86 ]. Luukkainen 1986 observed that women using the LNG-20 IUS were more likely to report an increase in headaches and acne than women using the Nova-T IUD, but it was not possible to extract these data for the meta-analysis. The life table differences indicate there were no significant differences between the expulsion rates of these two methods (Table 04). However, the rate ratios suggest that women using the LNG-20 IUS are significantly less likely to have an expulsion after two years of follow up (Table 03). As it is data from one study used to calculate the life table differences (Baveja 1989) and data from two other studies used to calculate the summary rate ratios (Andersson 1994, Luukkainen 1986), it is impossible to ascertain what effect the different methods of analysis have had on the results or whether it is in fact caused by differ- ences in the shape of the different IUDs. Andersson 1994 found that LNG-20 IUS users were significantly less likely to experience PID, in particular younger women, but we were unable to use the data in the meta-analysis. No other data on adverse outcomes were collected.

Seven trials comparing Progestasert with non-hormonal IUDs $<=250 \mathrm{~mm} 2$ were were identified (Affandi 1980; Andrade 1988; Fylling 1979; Larsen 1981; Lavin 1983; Piazarro 1979; Rybo 1983) and two of these provided data that could be included in the meta-analysis, one comparing Progestasert with the Nova-T IUD (Fylling 1979) and other with the CuT 200 IUD (Larsen 1981). The reasons for exclusion of data from the meta-analyses was either because Progestaert was compared to methods that are no longer or have never been licensed (Affandi 1980; Andrade 1988; Piazarro 1979) or it was not possible to extract data (Lavin 1983; Rybo 1983) Both included trials ran for one year. The rate ratios for pregnancy, continuation of method, expulsion and ectopic pregnancy calculated for these studies are presented in Table 05 . No data for any of these outcomes were included in the metaanalysis. Lavin 1983 reported that Progestasert users were significantly more likely to experience intermenstrual spotting, but significantly less likely to experience dysmenorrhoea.

One comparison of Progestasert and non-medicated IUDs was included (Newton 1979) and women were followed up for one year. Rate ratios for pregnancy, expulsion, ectopic pregnancy, and discontinuation for a planned pregnancy or personal reasons calculated from this study are presented in Table 06. No data were included in the meta-analysis on menstrual disturbance or hormonal side effect outcomes.

One study which compared users of the LNG-20 IUS with users of subdermal implants, Norplant-2, was identified (Wang 1992). The rate ratios calculated for pregnancy, continuation, expulsion, ovarian cysts, breast cancer, and discontinuation due to hormonal side effects, menstrual side effects, device problems and/or adverse events are presented in Table 07. There were significant differences found in the rates of reported menstrual disturbance. LNG-20 IUS users were significantly more likely to experience amenorrhoea compared to Norplant-2 users. The risk ratios were 2.27 [95\% CI 1.03 to 4.99] at one year follow up, 42.46 [95\% CI 2.62 to 689.20] at two years' follow up and 2.65 [95\% CI 0.53 to 13.20 ] at three years' follow up. They were also significantly more likely to experience oligomenorrhoea, risk ratio 6.17 [95\% CI 2.76 to 13.78] at two year follow up, although significant differences were not found at years' one and three follow up. LNG-20 IUS users were significantly less likely to experience spotting than Norplant2 users, risk ratios 0.33 [ $95 \%$ CI 0.18 to 0.60 ] at one year, 0.18 [95\% CI 0.07 to 0.5 ] at two years and 0.17 [95\% CI 0.05 to 0.57 ] at three years, and significantly less likely to have prolonged bleeding, risk ratios 0.13 [ $95 \%$ CI 0.05 to 0.35 ] at one year, 0.17 [95\% CI 0.06 to 0.46 ] at two years and 0.15 [95\% CI 0.04 to $0.64]$ at three years.

Hormonally impregnated intrauterine systems (IUSs) versus other forms of reversible contraceptives as effective methods of preventing 7 pregnancy 
There were no RCTs identified that compared IUSs with barrier, oral or injectable contraceptive methods.

\section{I S C U S S I O N}

There was insufficient evidence to suggest a difference in the pregnancy rates between LNG-20 IUS users and IUD $>250 \mathrm{~mm} 2$ users. The rate of pregnancy in LNG-20 IUS users was significantly lower than the rate in the IUD $<=250 \mathrm{~mm} 2$ users. Progestasert was significantly better at preventing pregnancy than the nonmedicated IUD after one year, but not when compared to copper IUDs $<=250 \mathrm{~mm} 2$.

When interpreting these findings on contraceptive effectiveness consideration must be paid to the limitations of the data. First, in the main, comparisons were of contraceptive methods with similar default states rather than comparisons of IUSs with methods where user adherence is likely to be a factor in effectiveness. Therefore, this review is unable to look at the relative advantages and disadvantages of contraceptive methods which rely on differing default states, such as comparing the LNG-20 IUS to oral contraceptives or to DMPA injections. Second, very large numbers of women would need to be recruited into these trials where in general the contraceptive methods being compared are highly effective in preventing unwanted pregnancy. Failure to detect a significant difference in contraceptive effectiveness between methods may be due to the small number of women enrolled and followed up in the included studies. Third, although life tables have been recommended as the most appropriate way to analyse contraceptive effectiveness data, and many of the included studies employed this method, confusion arose because of the inconsistent way these methods were defined and calculated. This resulted in some studies being excluded. It was much easier to extract data on number of events and women months or years from papers to provide an estimate akin to the Pearl Index.

Although it is useful to know how many unwanted pregnancies a method prevents, this information is of little value without collecting data on outcomes which reflect the acceptability of a method. A method may be efficacious in terms of preventing unwanted pregnancy, but if the method is discontinued within a short period of time its value as a method of contraception is greatly reduced. The meta-analyses conducted for continuation at yearly follow ups showed variable results between the different comparisons.

Few data could be extracted on hormonal side effects and menstrual disturbance. The one outcome that users of all types of IUSs were significantly more likely to experience was amenorrhoea. The fact that so little data were available was not necessarily because authors had not reported these outcomes, but was due to the ways these outcomes had been measured. For instance, some investigators reported a percentage of women experiencing an 'increase', 'decrease' and 'the same' as measurements for events, such as dys- menorrhoea or headaches. This does not allow baseline patterns on risk factors, such as age and parity, to be taken account of in the analysis.

The evidence on LNG-20 IUS suggested that women using this method were significantly more likely to expel the device than IUD $>250 \mathrm{~mm} 2$ users. It has been recommended that only health care workers who have received specialist training should insert and remove these methods in order to prevent local device problems. None of the studies reported whether or not health care workers had received specialist training, therefore we were not able to investigate the effect this had device expulsions.

Progestasert's license was not renewed in some countries because of concerns about increased risk of ectopic pregnancy when compared to copper bearing devices. Too few studies were eligible for inclusion in the meta-analysis for this risk to be accurately determined.

Discontinuation due menstrual changes per se is not an informative outcome as the LNG-20 and IUD >250mm2 comparison illustrates. Women using LNG-20 IUSs discontinued due to amenorrhoea, while IUD $>250 \mathrm{~mm} 2$ users discontinued because of bleeding and pain. The reporting of discontinuation due to amenorrhoea, bleeding and pain must be collected separately to provide a true picture.

An additional issue when interpreting data on discontinuation of methods due to menstrual changes is consideration of the 'cultural' setting in which the trials were conducted. For example, women from different backgrounds, as well as providers, may view menstrual change differently, as illustrated by the unpublished data from the Andersson study (Leiras Ltd 1999). Women should be informed of these potential side effects prior to starting these methods. The amenorrhoea in users of the LNG-20 IUS is benign and is due to high concentrations of levonorgestrel in the endometrium, the end organ (Scholten 1989). Therefore, if women (and providers) are informed amenorrhoea has no ill effect on their health (and for some with heavy menstrual bleeding it may have a positive effect), the acceptability of these methods may be improved.

\section{REVIEWERS'CONCLUSIONS}

\section{Implications for practice}

We found no significant difference in the risk of unwanted pregnancy between the LNG-20 IUS and IUDs $>250 \mathrm{~mm} 2$ or Norplant-2 although, given the very large numbers needed to provide adequate power to detect differences in uncommon events, this may reflect a lack of power in the included studies. We did find a lower risk of pregnancy when the LNG-20 IUS was compared to IUDs $<=250 \mathrm{~mm} 2$. 
Women using the LNG-20 IUS were more likely to experience amenorrhoea and this event was a notable reason for discontinuation. The much higher net ingredient cost (i.e. the device cost) of the LNG-20 IUS when compared to IUDs, with no discernible benefit in terms of contraceptive effectiveness when compared to IUDs $>250 \mathrm{~mm} 2$, may suggest that its use should be targeted at those women who are concerned about menstrual bleeding and pain with IUD use. All women who are considering a LNG-20 IUS should be informed of the possibility of amenorrhoea.

For the most part IUS users will be parous women who require contraception for birth spacing purposes. Therefore, rather than the results being generalisable to all women seeking contraception, these findings may be applicable to this group of women.

\section{Implications for research}

This systematic review highlighted the problems which arise because of inconsistent methods used to measure and report contraceptive effectiveness. Although we were not able to assess what impact these factors had on pooled data, standardised methods need to be encouraged.

It is vital that contraceptive effectiveness research is able to answer the queries and concerns of contraceptive users. Unfortunately, this has not been the case to date. Although rates of unplanned pregnancy, continuation and reasons for discontinuation of methods do provide information on acceptability and tolerability as well as effectiveness, many studies fail to report hormonal side effects and menstrual changes. Women's choice and acceptance of different methods is likely to be affected by acceptability, tolerability and availability of alternatives and the desire not to conceive. If lay contraceptive users are involved in research development, attention can be directed to answering questions of importance to consumers.

\section{POTENTIALCONFLICTOF I N T E R ES T}

None

\section{ACKNOWLEDGEMENTS}

We would like to thank for Ms. Betsy Anagnostelis input into the design of the search strategy. In addition we would like to thank Ms. Mani Gollopalli at the Institute of Child Health, Ms. Rita Ward at the International Planned Parenthood Federation and the fpa for their assistance in locating articles. The following individuals have assisted in trying to locate unpublished data and provided general advice: Ms. Walli Bounds (Margaret Pyke Family Planning Centre), Dr. Irvin Sivin (The Population Council), Dr. Patrick Rowe (World Health Organization), Dr. Catherine d'Arcangues (World Health Organization), Dr. Régine Sitruk-Ware (Laboratoire Théramex), Ms. Toni Belfield (fpa) and Dr. Iain Chalmers (The UK Cochrane Centre). The following pharmaceutical companies have co-operated with this work: Hoerchst Marion Roussel Ltd.

We would like to acknowledge the following for their help with the translation of papers: Dr. Kevin Fenton (Spanish and Portuguese), Dr. Yu Yi (Chinese), and Mr. Patrick Austin (Danish and Swedish).

Dr. Julian Higgins has provided much support and advice with the methodological aspects of conducting the meta-analyses. We would also like to acknowledge the support and encouragement received from the NHS Health Technology Assessment Proogramme and the Cochrane Fertility Regulation Review Group.

This work was funded by the National Health Service (NHS) Health Technology Assessment Programme. The opinions are those of the authors and not necessarily those of the NHS Executive.

\section{SOURCES OF S P PORT}

\section{External sources of support}

- National Health Service Health Technology Assessment Programme UK

Internal sources of support

- No sources of support supplied

\section{R E F E R E N C E S}

\section{References to studies included in this review}

Affandi 1980 \{published data only\}

*Affandi B, Moeloek FA, Saifuddin AB, Sumapraja S. Comparative study between IUDs: Lippes Loop, Cu T-200, Cu-7, and Progestasert. [Abstract]. Contraceptive Delivery Systems. conference. 1980; $1: 193$

Andersson 1994 \{published data only\}

Andersson K, Batar I, Rybo G. Return to fertility after removal of a levonorgestrel-releasing intrauterine device and Nova-T. Contracep- tion 1992;46:575-584

Andersson K, Odlind V, Rybo G. Levonorgestrel-releasing and copper-releasing (Nova T) IUDs during five years of use: a randomized comparative trial. Contraception 1994;49:56-72.

Lahteenmaki P, Shain RN, Ratsula K, et al. [One year experience of levonorgestrel-releasing intrauterine device] Ensimmaisen vuoden kokemukset levonorgestreeliehkaisimesta. Duodecim 1991;107:2631.

Hormonally impregnated intrauterine systems (IUSs) versus other forms of reversible contraceptives as effective methods of preventing 9 pregnancy

Copyright ( 2004 The Cochrane Collaboration. Published by John Wiley \& Sons, Ltd 
Luukkainen T, Allonen H, Haukkamaa M, et al. Effective contraception with the levonorgestrel-releasing intrauterine device: 12-month report of a European multicenter study. Contraception 1987;36:169179.

Rybo G, Andersson K, Odlind V. Hormonal intrauterine devices. Ann Med 1993;25:143-147.

Toivonen J, Luukkainen T, Allonen H. Protective effect of intrauterine release of levonorgestrel on pelvic infection: three years' comparative experience of levonorgestrel- and copper-releasing intrauterine devices. Obstet Gynecol 1991;77:261-264.

Andrade 1988 \{published data only\}

Andrade, Pizarro E, Shaw ST, Souza JP, Belsey EM, Rowe PJ. Consequences of uterine blood loss caused by various intrauterine contraceptive devices in South American women. Contraception 1988;38: $1-18$.

Baveja 1989 \{published data only\}

Baveja R, Bichille LK, Coyaji KJ, et al. Randomized clinical trial with intrauterine devices (levonorgestrel intrauterine device (LNG), CuT 380Ag, CuT 220C and CuT 200B). A 36-month study. Indian Council of Medical Research Task Force on IUD. Contraception 1989;39:37-52.

el Mahgoub 1982 \{published data only\}

el Mahgoub S. Long-term intracervical contraception with a levonorgestrel device. Contraception 1982;25:357-374.

el Mahgoub S. The norgestrel-T-IUD. Contraception 1980;22:271286.

Fylling 1979 \{published data only\}

Fylling P, Fagerhol M. Experience with two different medicated intrauterine devices: a comparative study of the Progestasert and NovaT. Fertil Steril 1979;31:138-141.

Heikkila 1982 \{published data only\}

Heikkila M. Puerperal insertion of a copper-releasing and a levonorgestrel-releasing intrauterine contraceptive device. Contraception 1982;25:561-572.

Larsen 1981 \{published data only\}

Larsen S, Hansen MK, Jacobsen JC, Ladehoff P, Sorensen T, Westergaard JG. [Progestasert and copper-T. A prospective, randomized clinical study of 2 coil types] Progestasert og kobber-T. En prospektiv, randomiseret klinisk undersogelse af to spiraltyper. Ugeskr Laeger 1981;143:13-14

Lavin 1983 \{published data only\} Lavin P, Bravo C, Waszak C. Comparison of T Cu 200 and Progestasert IUDs. Contraceptive Delivery Systems 1983;4:143-147.

Luukkainen 1986 \{published data only\}

Luukkainen T, Allonen H, Haukkamaa M, Lahteenmaki P, Nilsson CG, Toivonen J. Five years' experience with levonorgestrel-releasing IUDs. Contraception 1986;33:139-148.

Nilsson CG, Allonen H, Diaz J, Luukkainen T. Two years' experience with two levonorgestrel-releasing intrauterine devices and one copper-releasing intrauterine device: a randomized comparative performance study. Fertil Steril 1983;39:187-192.

Nilsson CG, Luukkainen T, Diaz J, Allonen H. Clinical performance of a new levonorgestrel-releasing intrauterine device. A randomized comparison with a nova-T-copper device. Contraception 1982;25: 345-356.

Nilsson CG, Luukkainen T, Diaz J, Allonen H. Intrauterine contraception with levonorgestrel: a comparative randomised clinical performance study. Lancet 1981;1:577-580.

Newton 1979 \{published data only\}

Newton J, Szontagh F, Lebech P, Rowe P. A collaborative study of the progesterone intrauterine device (Progestasert). The World Health Organization Task Force on Methods for the Regulation of Implantation. Contraception 1979;19:575-589.

Pakarinen 1996 \{published data only\}

Pakarinen P, Luukkainen T, Elomaa K, et al. A 12-month comparative clinical investigation of a levonorgestrel-releasing intracervical device situated in the uterine cavity or cervical canal. Contraception 1996; 54:187-192.

Piazarro 1979 \{published data only\}

Pizarro E, Gomez R, Rowe PJ, Lucero S. Comparative study of the Progesterone T (65 mcg daily) and Copper 7 IUD. Contraception. journal 1979;16:313-323.

Pizarro E, Gomez Rogers C, Rowe PJ. A comparative study of the effect of the Progestasert TM and Gravigard IUDs on dysmenorrhoea. Contraception 1979;20:455-466.

Rybo 1983 \{published data only\}

Rybo G, Bergqvist A. Comparison of menorrhagia with Progestasert and Cu-T-200. Rev Med Paris 1983;24:1463-1469.

Sivin 1994 \{published data only\}

Belhadj H, Sivin I, Diaz S, et al. Recovery of fertility after use of the levonorgestrel $20 \mathrm{mcg} / \mathrm{d}$ or Copper T $380 \mathrm{Ag}$ intrauterine device. Contraception 1986;34:261-267.

Sivin I, Alvarez F, Diaz J, et al. Intrauterine contraception with copper and with levonorgestrel: a randomized study of the TCu $380 \mathrm{Ag}$ and levonorgestrel $20 \mathrm{mcg}$ /day devices. Contraception 1984;30:443-456.

Sivin I, Stern J. Health during prolonged use of levonorgestrel 20 micrograms/d and the copper TCu 380Ag intrauterine contraceptive devices: a multicenter study. International Committee for Contraception Research (ICCR). Fertil Steril 1994;61:70-77.

Sivin I, Stern J, Coutinho E, et al. Prolonged intrauterine contraception: a seven-year randomized study of the levonorgestrel $20 \mathrm{mcg} / \mathrm{day}$ (LNg 20) and the Copper T380 Ag IUDS. Contraception 1991;44: 473-480.

Sivin I, Stern J, Diaz J, et al. Two years of intrauterine contraception with levonorgestrel and with copper: a randomized comparison of the $\mathrm{TCu} 380 \mathrm{Ag}$ and levonorgestrel $20 \mathrm{mcg} /$ day devices. Contraception 1987:35:245-255.

Sivin I, el Mahgoub S, McCarthy T, et al. Long-term contraception with the levonorgestrel $20 \mathrm{mcg} /$ day (LNg 20) and the copper T 380Ag intrauterine devices: a five-year randomized study. Contraception 1990;42:361-378.

Wang 1992 \{published data only\}

Gao J, Wang SL, Wu SC, Sun BL, Allonen H, Luukkainen T. Comparison of the clinical performance, contraceptive efficacy and acceptability of levonorgestrel-releasing IUD and Norplant-2 implants in China. Contraception 1990;41:485-494.

Hormonally impregnated intrauterine systems (IUSs) versus other forms of reversible contraceptives as effective methods of preventing 10 pregnancy

Copyright (C) 2004 The Cochrane Collaboration. Published by John Wiley \& Sons, Ltd 
Wang SL. [Comparative study of norplant-2 and levonorgestrelreleasing intrauterine devices]. Chung Hua Fu Chan Ko Tsa Chih 1990;25:232-4,253.

Wang SL, Wu SC, Xin XM, Chen JH, Gao J. Three years' experience with levonorgestrel-releasing intrauterine device and Norplant2 implants: a randomized comparative study. Adv Contracept 1992; 8:105-114

WHO 1983 \{published data only\}

Chompootaweep S, Reinprayoon D. A comparative clinical trial of Copper T $220 \mathrm{C}$ and Alza T IPCS 52 intrauterine devices in Thai women. Contraception 1986;33:437-442.

World Health Organization. The Alza T IPCS 52, a longer acting progesterone IUD: safety and efficacy compared to the TCu22OC and multiload 250 in two randomized multicentre trials. The World Health Organization's special programme of research, development and research training in human reproduction. Task Force on intrauterine devices for fertility regulation. Clin Reprod Fertil 1983;2: $113-128$.

WHO 1987 \{published data only\}

World Health Organization. Microdose intrauterine levonorgestrel for contraception. World Health Organization Special Programme of Research, Development and Research Training in Human Reproduction: Task Force on Intrauterine Devices for Fertility Regulation. Contraception 1987;35:363-379.

\section{References to studies excluded from this review Diaz 1993}

*Diaz J, Faundes A, Diaz M, Marchi N. Evaluation of the clinical performance of a levonorgestrel-releasing IUD, up to seven years of use, in Campinas, Brazil. Contraception 1993;47(2):169-75.

Faundes 1993

*Faundes A, Alvarez F, Diaz J. A Latin American experience with levonorgestrel IUD. Ann Med 1993;25:149-153.

Nilsson 1977

*Nilsson CG. Comparative quantification of menstrual blood loss with d-norgestrel releasing IUD and a Nova-T copper device. Contraception 1977;15:379-387.

\section{Nilsson 1986}

*Nilsson CG, Lahteenmaki PL, Luukkainen T, Robertson DN. Sustained intrauterine release of levonorgestrel over five years. Feril Steril 1986; 45:805-807.

Pedron Neueo 1992

*Pedron Neueo N. [Quantification of menstrual bleeding in women using intrauterine devices (IUDs)] Gaceta Medica de Mexico. journal 1992;128:597-604.

Ulstein 1987

*Ulstein M, Steier AJ, Hofstad T, Digranes A, Sandvei R. Microflora of cervical and vaginal secretion in women using copperand norgestrel-releasing IUCDs. Acta Obstet Gynecol Scand 1987;66: 321-322.

Yin 1993

*Yin M, Zhu P, Luo H, Xu R. The presence of mast cells in the human endometrium pre- and post-insertion of intrauterine devices. Contraception 1993;48:245-254.

\section{References to ongoing studies}

\section{WHO 1997}

Ongoing study Starting date of trial not provided. Contact reviewer for more information.

World Health Organization. Intrauterine Devices. Annual Technical Report 1997: 79 .

\section{Additional references}

Barrington 1997

Barrington JW, Bowen Simpkins P. The levonorgestrel intrauterine system in the management of menorrhagia. Br. J. Obstet. Gynaecol. journal 1997;104:614-616.

Dersimonian 1986

Dersimonian R, Laird N. Meta-analysis in clinical trials. Control Clin Trials 1986;7:177-88.

\section{Farley 1986}

Farley TM. Life-table methods for contraceptive research.. Statistics in Medicine 1986;5:475-489.

\section{Hasselblad 1995}

Hasselblad V, McCrory DC. Meta-analytic Tools for Medical Decision Making: A Practical Guide. Medical Decision Making 1995;15 (1):81-96.

Higgins 1985

Higgins JE, Wilkens LR. Statistical comparisons of Pearl rates. am J Obstet Gynecol. journal 1985;151:656-659.

\section{Irvine 1998}

Irvine GA, Campbell Brown MB, Lumsden MA, Heikkila A, Walker JJ, Cameron IT. Randomised comparative trial of the levonorgestrel intrauterine system and norethisterone for treatment of idiopathic menorrhagia. Br J Obstet Gynaecol. journal 1998;105:592-598.

\section{Leiras Ltd 1999}

Rauramo I. Leiras data. Personnal Communication 7th July, 1999.

\section{Mcguire 1995}

Mcguire A, Hughes, D. The Economics of Family Planning Services. . London: Family Planning Association 1995;1.

\section{Pearl 1933}

Pearl R. Factors in human fertility and their statistical evaluation. The Lancet 1933;2:607-611.

\section{Petitti 1994}

Petitti DB. Meta-analysis, Decision Analysis and Cost-Effectiveness Analysis. New York: Oxford University Press 1994;1:Oxford University Press, 1994.

\section{Potter 1966}

Potter RG. Application of Life Table Techniques to Measurement of Contraceptive Effectiveness. Demography. journal 1966;3:2897304 .

\section{Rodriguez 1976}

Rodriguez G, Faundes-Latham A, Atkinson L. An approach to the analyses of menstrual patterns in the critical evaluation of contraceptives. Studies in Family Planning. journal 1976;7:42-51.

\section{Schering 1999}

Schering Health Care Limited. Trademarks and countries document. Document Schering Health Care March 1999.

Hormonally impregnated intrauterine systems (IUSs) versus other forms of reversible contraceptives as effective methods of preventing I I pregnancy

Copyright (C) 2004 The Cochrane Collaboration. Published by John Wiley \& Sons, Ltd 
Scholten 1989

Scholten PC, van Eykeren MA, Christiaens GCML, Hospels AA. Menstrual blood loss with levonorgestrel, Nova-T and Multiload $\mathrm{Cu}$ 250 intrauterine devices. In: Scholten PC, editor(s). The levonorgestrel IUD clinical performance and impact on menstruation. Utrecht, The Netherlands: University Hospital, 1989.

Trussell 1991

Trussell J, Hatcher RA, Cates WJ, Stewart FH, Kost K. A guide to interpreting contraceptive efficacy studies. Obstet Gynecol. journal 1991:10:201-220

\section{References to other published versions of this review}

French 2000

French RS, Cowan FM, Mansour DJA, Morris S, Proctor T, Hughes D, Robinson A, Guillebaud J. Implantable contraceptives (subdermal implants and hormonally impregnated intrauterine systems) versus other forms of reversible contraceptives: two systematic reviews to assess relative effectiveness, acceptability, tolerability and costeffectiveness. Health Technology Assessment 2000;4(7).

*Indicates the major publication for the study

T A B LES

\section{Characteristics of included studies}

\begin{tabular}{ll} 
Study & Affandi $\mathbf{1 9 8 0}$ \\
\hline Methods & Setting: Indonesia \\
& 697 women randomised \\
& Follow up: 2 years \\
\hline Participants & Not stated \\
\hline Interventions & Progestasert [n=72] vs. CuT 200, Cu 7 and Lippes loop IUDs [n=75, 75 and 75, respectively] \\
\hline Outcomes & Pregnancy \\
& Reasons for discontinuation \\
\hline Notes & Abstract \\
& Quality assessment not conducted \\
\hline Allocation concealment & D \\
\hline
\end{tabular}

\begin{tabular}{ll} 
Study & Andersson $\mathbf{1 9 9 4}$ \\
\hline Methods & Setting: Multinational (Denmark, Finland, Hungary, Norway and Sweden), Family Planning Clinics (12) \\
& 2758 women randomised \\
& Follow up: 5 years \\
\hline Participants & $18-38$ years \\
& Parous \\
& Not breast feeding \\
\hline Interventions & LNG-20 IUS [n=1821] vs. Nova-T IUD [n=937] \\
\hline Outcomes & Pregnancy \\
\hline Hormonally impregnated intrauterine systems (IUSs) versus other forms of reversible contraceptives as effective methods of preventing
\end{tabular}

Hormonally impregnated intrauterine systems (IUSs) versus other forms of reversible contraceptives as effective methods of preventing pregnancy

Copyright (C) 2004 The Cochrane Collaboration. Published by John Wiley \& Sons, Ltd 


\section{Characteristics of included studies (Continued)}

Continuation

Reasons for discontinuation

Adverse events

Hormonal side effects

Pregnancy after discontinuation of method

\begin{tabular}{ll}
\hline Notes & Quality assessment: \\
& Randomisation technique: No mention \\
& Allocation concealment technique: Centrally prepared envelopes \\
& Description of prior contraceptive method / pregnancy provided \\
& Mesurement: Groups treated identically \\
& Method of analysis: Life tables (multiple and single decrement rates) \\
& User/method failure reported \\
\hline Allocation concealment & B \\
\hline
\end{tabular}

\begin{tabular}{ll} 
Study & Andrade 1988 \\
\hline Methods & Setting: Chile and Brazil (see Notes), Hospital \\
& $\begin{array}{l}150 \text { women randomised } \\
\text { Follow up: 2 years }\end{array}$ \\
\hline Participants & Parous \\
\hline Interventions & Progestasert [n=49] vs. Lippes lopp and Cu 7 IUDs [n=51 and 50, respectively] \\
\hline Outcomes & Menstrual blood loss \\
& Iron status \\
\hline Notes & Brazil group excluded because not randomised \\
& Quality assessment: \\
& Randomisation technique: Random number table \\
& Allocation concealment technique: No mention \\
& Description of prior contraceptive method / pregnancy provided \\
& Method of analysis: Not applicable \\
\hline Allocation concealment & D \\
\hline
\end{tabular}

\begin{tabular}{ll} 
Study & Baveja 1989 \\
\hline Methods & Setting: India, Family Planning Clinics \\
& 2118 women randomised \\
& Follow up: 3 years \\
\hline Participants & $18-40$ years \\
& Proven fertility \\
& regular menses \\
\hline Interventions & LNG-20 IUS [n=475] vs. CuT 380Ag, CuT 220C and CuT 200B IUDs [n=434, 496 and 500, respectively] \\
\hline Outcomes & Pregancy \\
& Continuation \\
& Reasons for discontinuation \\
& Menstrual disturbance \\
\hline Notes & Quality assessment: \\
& Randomisation technique: Computed random numbers \\
& Allocation concealment technique: Sealed envelopes \\
& Measurement: Groups treated identically \\
& Method of analysis: Life tables (single decrement rates) \\
& User / method failure reported \\
\hline
\end{tabular}

Hormonally impregnated intrauterine systems (IUSs) versus other forms of reversible contraceptives as effective methods of preventing 13 pregnancy

Copyright $(2004$ The Cochrane Collaboration. Published by John Wiley \& Sons, Ltd 


\section{Characteristics of included studies (Continued)}

Allocation concealment A

\begin{tabular}{ll} 
Study & Fylling 1979 \\
\hline Methods & Setting: Denmark \\
& 326 women randomised \\
& Follwo up: 1 year \\
\hline Participants & Mixed parity \\
\hline Interventions & Progestasert [n=162] vs. Nova-T IUD [n=164] \\
\hline Outcomes & Pregnancy \\
& Continuation \\
& Reasons for discontinuation \\
& Serum immunoglobin levels \\
\hline Notes & Quality assessment: \\
& Randomisation technique: No mention \\
& Allocation concealment technique: No mention \\
& Measurement: Groups treated identically \\
& Method of analysis: Other \\
\hline Allocation concealment & D \\
\hline
\end{tabular}

\begin{tabular}{ll} 
Study & Heikkila $\mathbf{1 9 8 2}$ \\
\hline Methods & Setting: Finland, Maternity Unit \\
& 80 women randomised \\
& Follow up: 1 year \\
\hline Participants & Postpartum \\
& Amenorrhoeic \\
& Breast feeding \\
\hline Interventions & LNG-30 IUS[n=40] vs. Nova-T IUD [n=40] \\
\hline Outcomes & Pregnancy \\
& Continuation \\
& Reasons for discontinuation \\
& Hormonal side effects \\
& Menstrual disturbance \\
& LNG plasma concentration \\
\hline Quality assessment: \\
Randomisation technique: No mention \\
Allocation concealment technique: No mention \\
Description of prior contraceptive method / pregnancy provided \\
Method of analysis: Other \\
User / method failure reported: Not applicable \\
\hline Allocation concealment & D \\
\hline
\end{tabular}

\begin{tabular}{ll} 
Study & Larsen $\mathbf{1 9 8 1}$ \\
\hline Methods & Setting: Denmark \\
& 382 women randomised \\
& Follow up: 1 year \\
\hline Participants & 15-44 years \\
& Variable parity \\
\hline
\end{tabular}

Hormonally impregnated intrauterine systems (IUSs) versus other forms of reversible contraceptives as effective methods of preventing pregnancy

Copyright (C) 2004 The Cochrane Collaboration. Published by John Wiley \& Sons, Ltd 
Characteristics of included studies (Continued)

\begin{tabular}{ll} 
Interventions & Progestasert [n=196] vs. CuT 200 IUD [n=186] \\
\hline Outcomes & Pregnancy \\
& Continuation \\
& Reasons for discontinuation \\
\hline Notes & Quality assessment: \\
& Randomisation technique: No mention \\
& Allocation concealment technique: No mention \\
& Women blinded to method \\
& Measurement: Groups treated identically \\
& Method of analysis: Life tables (multiple decrement rates) \\
\hline Allocation concealment & D \\
\hline
\end{tabular}

\begin{tabular}{|c|c|}
\hline Study & Lavin 1983 \\
\hline Methods & $\begin{array}{l}\text { Setting: Chile, Maternity Unit } \\
400 \text { women randomised } \\
\text { Follow up: } 1 \text { year }\end{array}$ \\
\hline Participants & Postpartum \\
\hline Interventions & $\begin{array}{l}\text { Progestasert [n=200] vs. CuT } 200 \text { IUD [n=200] - } 100 \text { inserted by hand and } 100 \text { inserted an inserter in each } \\
\text { group }\end{array}$ \\
\hline Outcomes & $\begin{array}{l}\text { Pregnancy } \\
\text { Continuation } \\
\text { Menstrual disturbance }\end{array}$ \\
\hline$\overline{\text { Notes }}$ & $\begin{array}{l}\text { Quality assessment: } \\
\text { Randomisation technique: No mention } \\
\text { Allocation concealment technique: No mention } \\
\text { Description of prior contraceptive method / pregnancy provided } \\
\text { Measurement: Groups treated identically } \\
\text { Method of analysis: Other }\end{array}$ \\
\hline Allocation concealment & $\mathrm{D}$ \\
\hline Study & Luukkainen 1986 \\
\hline Methods & $\begin{array}{l}\text { Setting: Finland and Brazil, Family Planning Clinics } \\
484 \text { women randomised } \\
\text { Follow up: } 2 \text { years (Brazil and Finland) and } 5 \text { years (Finland only) }\end{array}$ \\
\hline Participants & $\begin{array}{l}18-40 \text { years } \\
\text { Proven fertility } \\
\text { Not breast feeding }\end{array}$ \\
\hline Interventions & $\begin{array}{l}\text { LNG- } 20 \text { and LNG-30 IUSs [ } \mathrm{n}=164 \text { and 163, respectively] vs. } \\
\text { Nova-T IUD [ } \mathrm{n}=157]\end{array}$ \\
\hline$\overline{\text { Outcomes }}$ & $\begin{array}{l}\text { Pregnancy } \\
\text { Continuation } \\
\text { Resaons for discontinuation } \\
\text { Hormonal side effects } \\
\text { Menstrual disturbance }\end{array}$ \\
\hline Notes & $\begin{array}{l}\text { Quality assessment: } \\
\text { Randomisation technique: Random tables (permutations of nine numbers) } \\
\text { Allocation concealment technique: No mention } \\
\text { Description of prior contraceptive method / pregnancy provided }\end{array}$ \\
\hline
\end{tabular}

Hormonally impregnated intrauterine systems (IUSs) versus other forms of reversible contraceptives as effective methods of preventing I5 pregnancy

Copyright $\odot 2004$ The Cochrane Collaboration. Published by John Wiley \& Sons, Ltd 


\section{Characteristics of included studies (Continued)}

Double-blinded assessment of outcomes

Measurement: Groups treated identically

Method of analysis: Pearl Indices and life tables (multiple and single decrement rates)

User / method failure reported

Allocation concealment D

\begin{tabular}{ll} 
Study & Newton 1979 \\
\hline Methods & Setting: Clinics (4) \\
& 676 women randomised \\
& Follow up: 1year \\
\hline Participants & Various parity \\
\hline Interventions & Progestasert [n=359] vs. inert IUD [n=317] \\
\hline Outcomes & Pregnancy \\
& Continuation \\
& Reasons for discontinuation \\
& Menstrual disturbance \\
\hline Notes & Quality assessment: \\
& Randomisation technique: No mention \\
& Allocation concealment: 'both types of device were externally identical' \\
& Double-blinded assessment of outcomes \\
& Measurement: Groups treated identically \\
& Method of analysis: Life tables \\
\hline Allocation concealment & B \\
\hline
\end{tabular}

\section{Study}

Methods

\section{Pakarinen 1996}

Setting: Finland, Family Planning Clinics

298 women randomised

Follow up: 1 year

\begin{tabular}{ll}
\hline Participants & 18-43 years \\
& Variable parity \\
& Regular menses \\
\hline Interventions & LNG-20 IUS [n=147] vs. LNG-20 ICD [n=151] \\
\hline Outcomes & Pregnancy \\
& Continuation \\
& Reasons for discontinuation \\
& Hormonal side effects \\
\hline Notes & Quality assessment: \\
& Randomisation technique: Random number table with group allocation predetermined \\
& Allocation concealment technique: Consecutively numbered opaque sealed envelopes opened just before IUS \\
& insertion \\
& Measurement: Groups treated identically \\
& Method of analysis: Life tables (single decrement rates) \\
& User / method failure reported \\
\hline Allocation concealment & A
\end{tabular}

\begin{tabular}{ll} 
Study & Piazarro 1979 \\
\hline Methods & Setting: Chile, Family Planning Clinics \\
& 295 women randomised \\
\hline
\end{tabular}

Hormonally impregnated intrauterine systems (IUSs) versus other forms of reversible contraceptives as effective methods of preventing 16 pregnancy

Copyright (c) 2004 The Cochrane Collaboration. Published by John Wiley \& Sons, Ltd 


\section{Characteristics of included studies (Continued)}

\begin{tabular}{ll} 
& Follow up: 1 year \\
\hline Participants & P-40 years \\
& Parous \\
& Regular menses \\
\hline Interventions & Progesterone T IUS [n=146] vs. Cu 7 IUD [n=149] \\
\hline Outcomes & Pregnancy \\
& Continuation \\
& Reasons for discontinuation \\
& Menstrual disturbance \\
\hline Notes & Quality assessment: \\
& Randomisation technique: Computed tables \\
& Allocation concealment technique: No mention \\
& Description of prior contraceptive method / pregnancy reported \\
& Blinded assessment of outcomes \\
& Measurement: Groups treated identically \\
& Method of analysis: Life tables (method not stated) \\
& User / method failure reported \\
\hline Allocation concealment & D \\
\hline
\end{tabular}

\begin{tabular}{|c|c|}
\hline Study & Rybo 1983 \\
\hline Methods & $\begin{array}{l}\text { Setting: France } \\
\text { Follow up: }<1 \text { year } \\
30 \text { women randomised }\end{array}$ \\
\hline Participants & $\begin{array}{l}24-42 \text { years } \\
\text { Multiparous }\end{array}$ \\
\hline Interventions & Progestasert [n=13] vs. CuT 200 IUD [n=17] \\
\hline Outcomes & $\begin{array}{l}\text { Pregnancy } \\
\text { Menstrual disturbance and blood loss }\end{array}$ \\
\hline$\overline{\text { Notes }}$ & $\begin{array}{l}\text { Quality assessment: } \\
\text { Randomisation technique: No mention } \\
\text { Allocation concealment technique: No mention } \\
\text { Measurement: Groups treated identically } \\
\text { Method of analysis: Other }\end{array}$ \\
\hline Allocation concealment & $\mathrm{D}$ \\
\hline Study & Sivin 1994 \\
\hline Methods & $\begin{array}{l}\text { Setting: Multinational (Singapore, Brazil, Egypt and USA), Family Planning Clinics } \\
2226 \text { women randomised } \\
\text { Follow up: } 7 \text { years }\end{array}$ \\
\hline Participants & $\begin{array}{l}18-38 \text { years } \\
\text { Parous }\end{array}$ \\
\hline Interventions & LNG-20 IUS [n=1125] vs. CuT 380Ag IUD [n=1121] \\
\hline Outcomes & $\begin{array}{l}\text { Pregnancy } \\
\text { Continuation } \\
\text { Reasons for discontinuation } \\
\text { Insertion problems } \\
\text { Hormonal side effects } \\
\text { Menstrual disturbance }\end{array}$ \\
\hline
\end{tabular}

Hormonally impregnated intrauterine systems (IUSs) versus other forms of reversible contraceptives as effective methods of preventing I7 pregnancy

Copyright $\odot 2004$ The Cochrane Collaboration. Published by John Wiley \& Sons, Ltd 


\section{Characteristics of included studies (Continued)}

\begin{tabular}{|c|c|}
\hline & $\begin{array}{l}\text { Adverse events } \\
\text { Pregnancy after discontinuation of method }\end{array}$ \\
\hline Notes & $\begin{array}{l}\text { Quality assessment: } \\
\text { Randomisation technique: Random numbers - blocks of } 50 \text { Allocation concealment: Sealed opaque envelopes } \\
\text { openned in ascending numerical order } \\
\text { Women blinded to method } \\
\text { Measurement: Groups treated identically } \\
\text { Method of analysis: Life tables (multiple and single decrement rates) } \\
\text { User / method failure reported } \\
\text { Active follow up conducted }\end{array}$ \\
\hline Allocation concealment & $\mathrm{A}$ \\
\hline Study & WHO 1983 \\
\hline Methods & $\begin{array}{l}\text { Multinational ( } 13 \text { countries), Family Planning Clinics } \\
5542 \text { women randomised ( } 2514 \text { birth spacing insertion and } 3028 \text { post abortion insertion) } \\
\text { Follow up: } 2 \text { years }\end{array}$ \\
\hline Participants & $16-40$ years \\
\hline Interventions & $\begin{array}{l}\text { 1. Alza T IPCS } 52 \text { [n=1254] vs. CuT 220C IUD [n=1260] - interval insertion } \\
\text { 2. Alza T IPCS } 52 \text { [n=985] vs. CuT 220C and Multiload IUDs [n=1032 and 1011, respectively] - post } \\
\text { abortion insertion }\end{array}$ \\
\hline Outcomes & $\begin{array}{l}\text { Pregnancy } \\
\text { Continuation } \\
\text { Reasons for disconyinuation }\end{array}$ \\
\hline Notes & $\begin{array}{l}\text { Quality assessment: } \\
\text { Randomisation technique: Computed random tables } \\
\text { Allocation concealment technique: Sealed envelopes } \\
\text { Measurement: Groups treated identically } \\
\text { Method of analysis: Life tables (single decrement rates) } \\
\text { User / method failure reported } \\
\text { Active follow up conducted }\end{array}$ \\
\hline$\overline{\text { Allocation concealment }}$ & $\mathrm{A}$ \\
\hline
\end{tabular}

\begin{tabular}{ll} 
Study & WHO $\mathbf{1 9 8 7}$ \\
\hline Methods & Multinational (Thailand, China, India, Vietnam, Cuba, Russia, Yugloslavia and Zambia) \\
& $\begin{array}{l}4182 \text { women randomised } \\
\text { Follow up: 2 years }\end{array}$ \\
\hline Participants & $16-40$ years \\
& Parous \\
\hline Interventions & LNG-2 IUS [n=1377] vs. CuT 220C and Nova-T IUDS [n=1412 and 1393, respectively] \\
\hline Outcomes & Pregnancy \\
& Continuation Reasons fo discontinuation \\
\hline Notes & Quality assessment: \\
& Randomisation technique: Computed tables Allocation concealment technique: Sealed envelopes \\
& Measurement: Groups treated identically \\
& Method of analysis: Life tables (single decrement rates) \\
& User / method failure reported \\
& Active follow up conducted \\
\hline Allocation concealment & A \\
\hline Z
\end{tabular}

Hormonally impregnated intrauterine systems (IUSs) versus other forms of reversible contraceptives as effective methods of preventing I8 pregnancy

Copyright () 2004 The Cochrane Collaboration. Published by John Wiley \& Sons, Ltd 


\begin{tabular}{|c|c|}
\hline Study & Wang 1992 \\
\hline Methods & $\begin{array}{l}\text { Setting: China, Family Planning Clinics } \\
200 \text { women randomised } \\
\text { Follow up: } 3 \text { years }\end{array}$ \\
\hline Participants & $\begin{array}{l}20-40 \text { years } \\
\text { Parous } \\
\text { Not breast feeding }\end{array}$ \\
\hline Interventions & LNG-20 IUS [n=100] vs. Norplant-2 [n=100] \\
\hline Outcomes & $\begin{array}{l}\text { Pregnancy } \\
\text { Continuation } \\
\text { Reasons for discontinuation } \\
\text { Menstrual disturbance } \\
\end{array}$ \\
\hline Notes & $\begin{array}{l}\text { Quality assessment: } \\
\text { Randomisation technique: Sequential identication number } \\
\text { Allocation concealment technique: } \\
\text { Sealed envelopes } \\
\text { Description of prior contraceptive method / pregnancy provided } \\
\text { Meseasurement: Groups treated identically } \\
\text { Method of analysis: Life tables (single decrement rates) } \\
\text { User / method failure reported }\end{array}$ \\
\hline Allocation concealment & A \\
\hline Study & el Mahgoub 1982 \\
\hline Methods & $\begin{array}{l}\text { Setting: Egypt, Family Planning Clinics } \\
300 \text { women randomised } \\
\text { Follow up: } 3 \text { years }\end{array}$ \\
\hline Participants & $\begin{array}{l}15-40 \text { years } \\
\text { Parous } \\
\text { Hormonal contraceptive users at enrollment and immediate post partum women excluded }\end{array}$ \\
\hline Interventions & LNG-10 IUS and Norgestrel T (various doses) IUSs vs. CuT 200 IUD [n=100 in each group] \\
\hline Outcomes & $\begin{array}{l}\text { Pregnancy } \\
\text { Continuation } \\
\text { Reasons for discontinuation } \\
\text { Menstrual disturbance and blood loss } \\
\text { Endometrial and cervical cell changes }\end{array}$ \\
\hline Notes & $\begin{array}{l}\text { Quality assessment: } \\
\text { Randomisation technique: No mention } \\
\text { Allocation concealment technique: No mention } \\
\text { Description of prior contraceptive method / pregnancy provided } \\
\text { Method of analysis: Life tables (method not stated) }\end{array}$ \\
\hline Allocation concealment & $\mathrm{D}$ \\
\hline
\end{tabular}

\section{Characteristics of excluded studies}

\begin{tabular}{ll} 
Study & Reason for exclusion \\
\hline Diaz 1993 & Intervention: LNG-IUS vs. CuT 380Ag IUD \\
& Primary outcomes: Pregnancy, continuation and reasons for discontinuation \\
\hline
\end{tabular}

Hormonally impregnated intrauterine systems (IUSs) versus other forms of reversible contraceptives as effective methods of preventing 19 pregnancy

Copyright $\odot 2004$ The Cochrane Collaboration. Published by John Wiley \& Sons, Ltd 


\section{Characteristics of excluded studies (Continued)}

Only report outcomes for LNG-IUS users. Comparative results reported elsewhere (see Sivin 1994)

Faundes $1993 \quad$ Intervention: LNG-IUS vs. CuT 380Ag IUD

Primary outcomes: Pregnancy, continuation, reasons for discontinuation, ovarian function and LNG serum levels

Only report outcomes for LNG-users. Comparative results reported elsewhere (see Sivin 1994)

Nilsson 1977 Intervention: d-norgestrel releasing IUS vs. Nova-T 200 IUD

Primary outcomes: Menstrual blood loss

Reported outcomes not relevant to review

Nilsson 1986 Intervention: LNg-20 IUS vs. LNG-30 IUS

Primary outcomes: Plasma concentration of LNG

Reported outcomes not relevant to review (other publications of study included - see Luukkainen 1986)

Pedron Neueo 1992 Intervention: Various IUSs and IUDs (11)

Primary outcomes: Menstrual blood loss

Reported outcomes not relevant to review

Ulstein 1987 Intervention: LNG-IUS vs. copper IUD

Primary outcomes: Changes in cervical and vaginal microflora

Reported outcomes not relevant to review

Yin 1993

Intervention: LNG-IUS, stainless steel ring and CuT 220 IUD

Primary outcomes: Endometrial mast cell density

Reported outcomes not relevant to review

\section{Characteristics of ongoing studies}

\begin{tabular}{ll} 
Study & WHO 1997 \\
\hline Trial name or title & \\
\hline Participants & $\begin{array}{l}\text { International multicentre (20) } \\
\text { 3384 women randomised }\end{array}$ \\
\hline Interventions & LNG-20 IUS (n=1693) vs. CuT 380A (N=1691) \\
\hline Outcomes & $\begin{array}{l}\text { Pregnancy } \\
\text { Continuation } \\
\text { Reseaons for discontinuation }\end{array}$ \\
\hline Starting date & \\
\hline Contact information & \\
\hline Notes
\end{tabular}

\section{G R A P H S}

\section{Comparison 01. LNG-20 IUS vs. IUDs $>250 \mathrm{~mm} 2$}

\begin{tabular}{|c|c|c|c|c|}
\hline Outcome title & $\begin{array}{l}\text { No. of } \\
\text { studies }\end{array}$ & $\begin{array}{c}\text { No. of } \\
\text { participants }\end{array}$ & Statistical method & Effect size \\
\hline Pregnancy due to method failure & & & Other data & No numeric data \\
\hline Continuation of method & & & Other data & No numeric data \\
\hline $\begin{array}{l}\text { Planned pregnancy after } \\
\text { discontinuation of method }\end{array}$ & 1 & 86 & Peto Odds Ratio 95\% CI & $1.25[0.45,3.48]$ \\
\hline Amenorrhoea & 2 & 700 & Peto Odds Ratio 95\% CI & $5.29[3.64,7.68]$ \\
\hline Prolonged bleeding & 2 & 700 & Peto Odds Ratio 95\% CI & $0.80[0.51,1.26]$ \\
\hline Expulsion & & & Other data & No numeric data \\
\hline
\end{tabular}

Hormonally impregnated intrauterine systems (IUSs) versus other forms of reversible contraceptives as effective methods of preventing 20 pregnancy

Copyright (C) 2004 The Cochrane Collaboration. Published by John Wiley \& Sons, Ltc 
Embedded

Ectopic pregnancy

Pelvic inflammatory disease

Hormonal reasons for discontinuation

Menstrual reasons for discontinuation: all

Menstrual reasons for discontinuation: bleeding $\&$ pain

Menstrual reasons for discontinuation: pain

Menstrual reasons for discontinuation: amenorrhoea

Discontinuation due to adverse event

Discontinuation because planning pregnancy

Personal reasons for discontinuation
Other data

Other data

Other data

Other data

Other data

Other data

Other data

Other data

Other data

Other data

Other data
No numeric data

No numeric data

No numeric data

No numeric data

No numeric data

No numeric data

No numeric data

No numeric data

No numeric data

No numeric data

No numeric data

\section{Comparison 02. LNG-20 IUS vs. IUD $<=250 \mathrm{~mm} 2$}

\begin{tabular}{|c|c|c|c|c|}
\hline Outcome title & $\begin{array}{l}\text { No. of } \\
\text { studies }\end{array}$ & $\begin{array}{c}\text { No. of } \\
\text { participants }\end{array}$ & Statistical method & Effect size \\
\hline Pregnancy due to method failure & & & Other data & No numeric data \\
\hline Continuation of method & & & Other data & No numeric data \\
\hline $\begin{array}{l}\text { Planned pregnancy after } \\
\text { discontinuation of method }\end{array}$ & & & Peto Odds Ratio 95\% CI & Totals not selected \\
\hline Headaches & 1 & 1051 & Peto Odds Ratio 95\% CI & $1.62[0.53,4.92]$ \\
\hline Breast tenderness & 1 & 1051 & Peto Odds Ratio 95\% CI & $1.45[0.35,6.07]$ \\
\hline Acne & 1 & 1051 & Peto Odds Ratio 95\% CI & $3.01[0.95,9.51]$ \\
\hline Nausea & 1 & 1051 & Peto Odds Ratio 95\% CI & $4.18[0.20,86.14]$ \\
\hline Ovarian cysts & & & Other data & No numeric data \\
\hline Expulsion & & & Other data & No numeric data \\
\hline Ectopic pregnancy & & & Other data & No numeric data \\
\hline Pelvic inflammatory disease & & & Other data & No numeric data \\
\hline $\begin{array}{l}\text { Hormonal reasons for } \\
\text { discontinuation }\end{array}$ & & & Other data & No numeric data \\
\hline $\begin{array}{l}\text { Menstrual reasons for } \\
\text { discontinuation: all }\end{array}$ & & & Other data & No numeric data \\
\hline $\begin{array}{l}\text { Menstrual reasons for } \\
\text { discontinuation: bleeding } \& \\
\text { pain }\end{array}$ & & & Other data & No numeric data \\
\hline $\begin{array}{l}\text { Menstrual reasons for } \\
\text { discontinuation: amenorrhoea }\end{array}$ & & & Other data & No numeric data \\
\hline $\begin{array}{l}\text { Discontinuation due to adverse } \\
\text { event }\end{array}$ & & & Other data & No numeric data \\
\hline $\begin{array}{l}\text { Discontinuation because planning } \\
\text { pregnancy }\end{array}$ & & & Other data & No numeric data \\
\hline
\end{tabular}

Hormonally impregnated intrauterine systems (IUSs) versus other forms of reversible contraceptives as effective methods of preventing 2 I pregnancy

Copyright (C) 2004 The Cochrane Collaboration. Published by John Wiley \& Sons, Ltd 
Comparison 03. LNG-20 IUS vs. Norplant-2

\begin{tabular}{|c|c|c|c|}
\hline Outcome title & $\begin{array}{lc}\begin{array}{l}\text { No. of } \\
\text { studies }\end{array} & \begin{array}{c}\text { No. of } \\
\text { participants }\end{array} \\
\end{array}$ & Statistical method & Effect size \\
\hline Pregnancy & & Other data & No numeric data \\
\hline Continuation of method & & Other data & No numeric data \\
\hline Expulsion & & Other data & No numeric data \\
\hline Breast cancer & & Other data & No numeric data \\
\hline Ovarian cysts & & Other data & No numeric data \\
\hline Spotting & & Peto Odds Ratio 95\% CI & Subtotals only \\
\hline Oligomenorrhoea & & Peto Odds Ratio 95\% CI & Subtotals only \\
\hline Amenorrhoea & & Peto Odds Ratio 95\% CI & Subtotals only \\
\hline Prolonged bleeding & & Peto Odds Ratio 95\% CI & Subtotals only \\
\hline
\end{tabular}

\section{Comparison 04. Progestasert vs. IUDs $<=250 \mathrm{~mm} 2$}

\begin{tabular}{|c|c|c|c|c|}
\hline Outcome title & $\begin{array}{l}\text { No. of } \\
\text { studies }\end{array}$ & $\begin{array}{c}\text { No. of } \\
\text { participants }\end{array}$ & Statistical method & Effect size \\
\hline Pregnancy & & & Other data & No numeric data \\
\hline Continuation of method & & & Other data & No numeric data \\
\hline Expulsion & & & Other data & No numeric data \\
\hline Ectopic pregnancy & & & Other data & No numeric data \\
\hline $\begin{array}{l}\text { Menstrual reasons for } \\
\text { discontinuation: bleeding } \& \\
\text { pain }\end{array}$ & & & Other data & No numeric data \\
\hline
\end{tabular}

\section{Comparison 05. Progestasert vs. non-medicated IUD}

\begin{tabular}{|c|c|c|c|}
\hline Outcome title & $\begin{array}{lc}\begin{array}{l}\text { No. of } \\
\text { studies }\end{array} & \begin{array}{c}\text { No. of } \\
\text { participants }\end{array} \\
\end{array}$ & Statistical method & Effect size \\
\hline Pregnancy & & Other data & No numeric data \\
\hline Continuation of method & & Other data & No numeric data \\
\hline Expulsion & & Other data & No numeric data \\
\hline Ectopic pregnancy & & Other data & No numeric data \\
\hline $\begin{array}{l}\text { Menstrual reasons for } \\
\text { discontinuation: all }\end{array}$ & & Other data & No numeric data \\
\hline $\begin{array}{l}\text { Discontinuation because planning } \\
\text { pregnancy }\end{array}$ & & Other data & No numeric data \\
\hline $\begin{array}{l}\text { Discontinuation for personal } \\
\text { reasons }\end{array}$ & & Other data & No numeric data \\
\hline
\end{tabular}

\section{COVER SHEET}

Title

Authors

Contribution of author(s)
Hormonally impregnated intrauterine systems (IUSs) versus other forms of reversible contraceptives as effective methods of preventing pregnancy

French R, Cowan F, Mansour D, Morris S, Hughes D, Robinson A, Proctor T, Summerbell C, Logan S, Guillebaud J

Rebecca French: Reviewer

Frances Cowan: Reviewer and supervisor

Hormonally impregnated intrauterine systems (IUSs) versus other forms of reversible contraceptives as effective methods of preventing 22 pregnancy

Copyright $\odot 2004$ The Cochrane Collaboration. Published by John Wiley \& Sons, Ltd 
John Guillebaud: Contraceptive advisor

Diana Mansour: Contraceptive advisor

Angela Robinson: Contraceptive advisor

Steve Morris: Health economist

Stuart Logan: Systematic review methodology advisor

Carolyn Summerbell: Systematic methodology advisor

Tanya Proctor: Lay representative

Issue protocol first published

$1998 / 4$

Date of most recent amendment 30 August 2003

Date of most recent

11 November 1999

SUBSTANTIVE amendment

What's New

DOI

Cochrane Library number

Editorial group

Editorial group code
Information not supplied by author

10.1002/14651858.CD001776

CD001776

Cochrane Fertility Regulation Group

HM-FERTILREG

\section{Comparison 05. Pregnancy due to method failure}

\section{GRAPHS ANDOTHER TABLES}

At 1 year

Study

Baveja 1989

Single decrement life table probabilities $(\mathrm{SE})=0.0(0.4)$ vs. $0.8(0.4)$

Sivin 1994

2/7680 women months vs. 2/7740 women months

Single decrement life table probabilities $(\mathrm{SE})=0.3(0.2)$ vs. $0.3(0.2)$

At 2 years

Study

Baveja 1989

Single decrement life table probabilities $(\mathrm{SE})=0.0(0.5)$ vs. $1.0(0.5)$

Sivin 1994

2/19644 women months vs. 7/20436 women months

At 3 years

Study

Baveja 1989

0/10589 women months vs. 4/10869 women months

Single decrement life table probabilities $(\mathrm{SE})=0.0(0.5)$ vs. $1.0(0.5)$

At 5 years

Study

Sivin 1994

6/34944 women months vs. $10 / 38268$ women months

Single decrement life table probabilities $(\mathrm{SE})=1.1(0.5)$ vs. $1.4(0.4)$

Hormonally impregnated intrauterine systems (IUSs) versus other forms of reversible contraceptives as effective methods of preventing 23 pregnancy

Copyright $\odot 2004$ The Cochrane Collaboration. Published by John Wiley \& Sons, Ltd 


\section{Comparison 05. Continuation of method}

At 1 year

Study

Baveja 1989

339/4809 women months vs. 350/4599 women months

Sivin 1994

$743 / 11892$ women months vs. 791/12084 women months Life table probabilities $(\mathrm{SE})=73.5(1.4)$ vs. $79.8(1.3)$

At 2 years

Study

Baveja 1989

$257 / 8321$ women months vs. $276 / 8333$

Sivin 1994

$548 / 19644$ women months vs. $605 / 20436$ women months Life table probabilities $(\mathrm{SE})=59.4$ (1.6) vs. 67.5 (1.5)

At 3 years

Study

Baveja 1989

$150 / 10589$ women months vs. $170 / 10869$ women months

At 5 years

Study

Sivin 1994

$298 / 34944$ women months vs. $335 / 38268$ women months Life table probabilities $(\mathrm{SE})=33(1.5)$ vs. $40.6(1.6)$

\section{Comparison 05. Planned pregnancy after discontinuation of method}

Review: Hormonally impregnated intrauterine systems (IUSs) versus other forms of reversible contraceptives as effective methods of preventing pregnancy Comparison: 0I LNG-20 IUS vs. IUDs $>250 \mathrm{~mm} 2$

Outcome: 03 Planned pregnancy after discontinuation of method

\begin{tabular}{|c|c|c|c|c|c|}
\hline Study & $\begin{array}{c}\text { Treatment } \\
\mathrm{n} / \mathrm{N}\end{array}$ & $\begin{array}{c}\text { Control } \\
n / N\end{array}$ & $\begin{array}{c}\text { Peto Odds Ratio } \\
95 \% \mathrm{Cl}\end{array}$ & $\begin{array}{c}\text { Weight } \\
(\%)\end{array}$ & $\begin{array}{c}\text { Peto Odds Ratio } \\
95 \% \mathrm{Cl}\end{array}$ \\
\hline \multicolumn{6}{|l|}{ 0I At I year } \\
\hline Sivin 1994 & $39 / 49$ & $28 / 37$ & - & 100.0 & $1.25[0.45,3.48]$ \\
\hline Total $(95 \% \mathrm{Cl})$ & 49 & 37 & & 100.0 & $1.25[0.45,3.48]$ \\
\hline \multicolumn{6}{|c|}{ Total events: 39 (Treatment), 28 (Control) } \\
\hline \multicolumn{6}{|c|}{ Test for heterogeneity: not applicable } \\
\hline Test for overall & $p=0.7$ & & & & \\
\hline
\end{tabular}

Hormonally impregnated intrauterine systems (IUSs) versus other forms of reversible contraceptives as effective methods of preventing 24 pregnancy

Copyright ( 2004 The Cochrane Collaboration. Published by John Wiley \& Sons, Ltd 


\section{Comparison 05. Amenorrhoea}

Review: Hormonally impregnated intrauterine systems (IUSs) versus other forms of reversible contraceptives as effective methods of preventing pregnancy Comparison: 0 I LNG-20 IUS vs. IUDs $>250 \mathrm{~mm} 2$

Outcome: 04 Amenorhoea

\begin{tabular}{|c|c|c|c|c|c|}
\hline Study & $\begin{array}{l}\text { Treatment } \\
\mathrm{n} / \mathrm{N}\end{array}$ & $\begin{array}{l}\text { Control } \\
n / N\end{array}$ & $\begin{array}{c}\text { Peto Odds Ratio } \\
95 \% \mathrm{Cl}\end{array}$ & $\begin{array}{c}\text { Weight } \\
(\%)\end{array}$ & $\begin{array}{c}\text { Peto Odds Ratio } \\
95 \% \mathrm{Cl}\end{array}$ \\
\hline \multicolumn{6}{|l|}{01 At 3 months } \\
\hline Sivin 1994 & $41 / 215$ & $20 / 226$ & 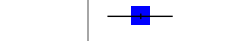 & 47.7 & $2.35[1.37,4.04]$ \\
\hline Subtotal $(95 \% \mathrm{Cl})$ & 215 & 226 & . & 47.7 & $2.35[1.37,4.04]$ \\
\hline \multicolumn{6}{|c|}{ Total events: 4I (Treatment), 20 (Control) } \\
\hline \multicolumn{6}{|c|}{ Test for heterogeneity: not applicable } \\
\hline \multicolumn{6}{|c|}{ Test for overall effect $z=3.10 \quad p=0.002$} \\
\hline \multicolumn{6}{|l|}{02 At 3 years } \\
\hline Sivin 1994 & $75 / 120$ & $12 / 139$ & $\rightarrow$ & 52.3 & $11.08[6.61,18.57]$ \\
\hline Subtotal $(95 \% \mathrm{Cl})$ & 120 & 139 & $\longrightarrow$ & 52.3 & $11.08[6.61,18.57]$ \\
\hline \multicolumn{6}{|c|}{ Total events: 75 (Treatment), 12 (Control) } \\
\hline \multicolumn{6}{|c|}{ Test for heterogeneity: not applicable } \\
\hline \multicolumn{6}{|c|}{ Test for overall effect $z=9.13 \quad p<0.00001$} \\
\hline Total $(95 \% \mathrm{Cl})$ & 335 & 365 & 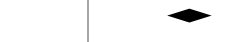 & 100.0 & $5.29[3.64,7.68]$ \\
\hline \multicolumn{6}{|c|}{ Total events: I I6 (Treatment), 32 (Control) } \\
\hline \multicolumn{6}{|c|}{ Test for heterogeneity chi-square $=|6.53 \mathrm{df}=| \mathrm{p}=<0.000 \mathrm{I} \mid=94.0 \%$} \\
\hline Test for overall effe & $p<0.0000$ । & & & & \\
\hline
\end{tabular}

$\begin{array}{lllllll}0.1 & 0.2 & 0.5 & 1 & 2 & 5 & 10\end{array}$

\section{Comparison 05. Prolonged bleeding}

Review: Hormonally impregnated intrauterine systems (IUSs) versus other forms of reversible contraceptives as effective methods of preventing pregnancy Comparison: 0 I LNG-20 IUS vs. IUDs $>250 \mathrm{~mm} 2$

Outcome: 05 Prolonged bleeding

Treatment Control

Peto Odds Ratio

Weight

Peto Odds Ratio

$\mathrm{n} / \mathrm{N}$

$\mathrm{n} / \mathrm{N}$

95\% Cl

$95 \% \mathrm{Cl}$

OI At 3 months

Sivin 1994

$42 / 215$

$49 / 226$

$\square$

(\%)

-

Subtotal $(95 \%$ Cl)

215

226

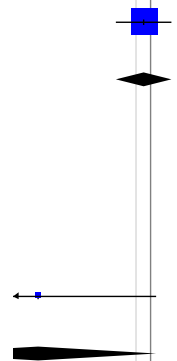

94.8

$0.88[0.55,1.39]$

Total events: 42 (Treatment), 49 (Control)

Test for heterogeneity: not applicable

Test for overall effect $z=0.56 \quad p=0.6$

02 At 3 years

Sivin 1994

$0 / 120$

$4 / 139$

120

139

Total events: 0 (Treatment), 4 (Control) 


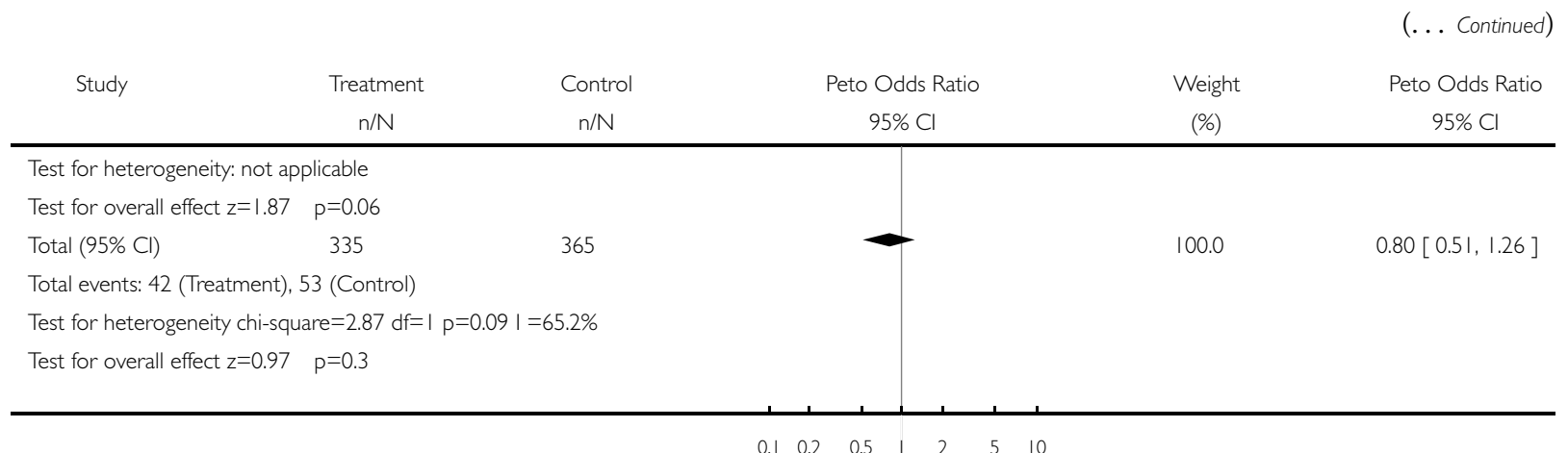

\section{Comparison 05. Expulsion}

At 1 year

Study

Baveja 1989

Sivin 1994

At 2 years

Study

Baveja 1989

At 3 years

Study

Baveja 1989

At 5 years

Study

Sivin 1994
Single decrement life table probabilities $(\mathrm{SE})=6.5(1.2)$ vs. $5.3(1.1)$

$43 / 7680$ women months vs. 39/7740 women months

Single decrement life table probabilities $(\mathrm{SE})=6.4(1.0)$ vs. $5.8(1.9)$

Single decrement life table probabilities $(\mathrm{SE})=9.2(1.4)$ vs. $7.1(1.3)$

Single decrement life table probabilities $(\mathrm{SE})=10.6(1.6)$ vs. $7.6(1.4)$

99/34944 women months vs. 71/38268 women months

Single decrement life table probabilities $(\mathrm{SE})=11.8(1.2)$ vs. $7.4(0.9)$

\section{Comparison 05. Embedded}

At 5 years

Study

Sivin 1994
3/34944 women months vs. 0/38268 women months

\section{Comparison 05 . Ectopic pregnancy}

Hormonally impregnated intrauterine systems (IUSs) versus other forms of reversible contraceptives as effective methods of preventing 26 pregnancy

Copyright ( 2004 The Cochrane Collaboration. Published by John Wiley \& Sons, Ltd 
At 1 year

Study

Sivin 1994

At 2 years

Study

Sivin 1994

At 5 years

Study

Sivin 1994

At 1 year

Study

Sivin 1994

At 1 year

Study

At 3 years

Study

Baveja 1989

At 5 years

Study

Sivin 1994
Sivin 1994

0/7680 women months vs. 0/7740 women months

0/19644 women months vs. 0/20436 women months

0/34944 women months vs. 2/38268 women months

\section{Comparison 05. Pelvic inflammatory disease}

10/7680 women months vs. 8/7740 women months

Single decrement life table probabilities $(\mathrm{SE})=1.6(0.5)$ vs. $1.3(0.4)$

\section{Comparison 05 . Hormonal reasons for discontinuation}

4/7680 women months vs. 5/7740 women months

Single decrement life table probabilities $(\mathrm{SE})=0.7(0.4)$ vs. $0.8(0.4)$

10/10589 women months vs. 6/10869 women months

31/34994 women months vs. 8/38268 women months

\section{Comparison 05. Menstrual reasons for discontinuation: all}

At 1 year

Study

Baveja 1989

Single decrement life table probabilities $(\mathrm{SE})=13.8(1.7)$ vs. 7.1 (1.3)

Sivin 1994
$69 / 7680$ women months vs. 47/7740 women months

Single decremt life table probabilities $(\mathrm{SE})=11.1(7.5)$ vs. $1.6(1.1)$

Hormonally impregnated intrauterine systems (IUSs) versus other forms of reversible contraceptives as effective methods of preventing 27 pregnancy

Copyright ( 2004 The Cochrane Collaboration. Published by John Wiley \& Sons, Ltd 
At 2 years

Study

Baveja 1989

At 3 years

Study

Baveja 1989

At 5 years

Study

Sivin 1994
Single decrement life table probabilities $(\mathrm{SE})=21.9(2.1)$ vs. $10.8(1.3)$

Single decrement life table probabilities $(\mathrm{SE})=27.9(2.3)$ vs. $13.4(1.8)$

\section{Comparison 05 . Menstrual reasons for discontinuation: bleeding \& pain}

At 5 years

Study

Sivin 1994
$118 / 34944$ women months vs. $183 / 38268$ women months

Single decrement life table probabilities $(\mathrm{SE})=15.4(1.4)$ vs. $23.3(0.6)$

\section{Comparison 05 . Menstrual reasons for discontinuation: pain}

At 1 year Study

Sivin 1994

At 5 years Study

Sivin 1994

$15 / 7680$ women months vs. 47/7740 women months

Single decrement life table probabilities $(\mathrm{SE})=19.7$ (1.6) vs. $0.4(0.2)$

\section{Comparison 05. Menstrual reasons for discontinuation: amenorrhoea}

At 1 year

Study

Sivin 1994

32/7680 women months vs. 0/7740 women months

Single decrement life table probabilities $(\mathrm{SE})=5.6$ (1.0) vs. 0.0

At 5 years

Study

Sivin 1994
$134 / 34944$ women months vs. $3 / 38268$ women months

Hormonally impregnated intrauterine systems (IUSs) versus other forms of reversible contraceptives as effective methods of preventing 28 pregnancy

Copyright ( 2004 The Cochrane Collaboration. Published by John Wiley \& Sons, Ltd 


\section{Comparison 05. Discontinuation due to adverse event}

At 3 years

Study

Baveja 1989
2/10589 women months vs. 2/10869 women months

\section{Comparison 05 . Discontinuation because planning pregnancy}

At 1 year

Study

Sivin 1994

At 5 years

Study

Sivin 1994
$15 / 7680$ women months vs. $16 / 7740$ women months

Single decrement life table probabilities $(\mathrm{SE})=2.8(0.7)$ vs. $2.9(0.7)$

$155 / 34944$ women months vs. $153 / 38268$ women months

Single decrement life table probabilities $(\mathrm{SE})=25.0$ (1.9) vs. 23.5 (1.7)

\section{Comparison 05. Personal reasons for discontinuation}

At 1 year

Study

Sivin 1994

At 5 years

Study

Sivin 1994

56/34944 women months vs. 55/38268 women months

Single decrement life table probabilities $(\mathrm{SE})=9.5(1.3)$ vs. $9.4(1.3)$

\section{Comparison 05. Pregnancy due to method failure}

At 1 year

Study

Andersson 1994

1/18664 women months vs. 8/9326 women months

Baveja 1989

Luukkainen 1986

Single decrement life table probabilities (SE) = 0.0 vs. CuT 220C 0.0 and vs. CuT 200B $0.9(0.4)$

1/1654 women months vs. 4/1708 women months

At 2 years

Study

Baveja 1989
Single decrement life table probabilities (SE) $=0.0$ vs. CuT 220C 0.0 and vs. CuT 200B 0.9 (0.4)

Hormonally impregnated intrauterine systems (IUSs) versus other forms of reversible contraceptives as effective methods of preventing 29 pregnancy

Copyright $\odot 2004$ The Cochrane Collaboration. Published by John Wiley \& Sons, Ltd 
At 3 years

Study

Andersson 1994

Baveja 1989
3/46200 women months vs. $24 / 23568$ women months

0/10589 women months vs. 7/24225 women months (vs. CuT 220C 1/12076 women months and vs. CuT 220B 6/12149 women months)

Single decrement life table probabilities $(\mathrm{SE})=0.0$ vs. CuT 220C $0.3(0.3)$ and vs. CuT 200B 1.6 (0.6)

\section{At 5 years}

Study

Andersson 1994

Luukkainen 1986
5/67380 women months vs. $35 / 33312$ women months

1/5495 women months vs. 7/5176 women months

\section{Comparison 05. Continuation of method}

\section{At 1 year}

\section{Study}

Andersson 1994

Baveja 1989

At 2 years

Study

Baveja 1989

At 3 years

Study

Andersson 1994

Baveja 1989

At 5 years

Study

Andersson 1994

Luukkainen 1986
$1362 / 18664$ women months vs. $680 / 9326$ women months $339 / 4809$ women months vs. $791 / 9814$ women months

$257 / 8321$ women months vs. $617 / 18819$ women months $902 / 46200$ women months vs. $435 / 23568$ women months $150 / 10589$ women months vs. $344 / 24255$ women months

67/5495 women months vs. 53/5176 women months

$736 / 67380$ women months vs. $315 / 33312$ women months

Hormonally impregnated intrauterine systems (IUSs) versus other forms of reversible contraceptives as effective methods of preventing 30 pregnancy

Copyright $\odot 2004$ The Cochrane Collaboration. Published by John Wiley \& Sons, Ltd 


\section{Comparison 05. Planned pregnancy after discontinuation of method}

Review: Hormonally impregnated intrauterine systems (IUSs) versus other forms of reversible contraceptives as effective methods of preventing pregnancy Comparison: 02 LNG-20 IUS vs. IUD $<=250 \mathrm{~mm} 2$

Outcome: 03 Planned pregnancy after discontinuation of method

\begin{tabular}{|c|c|c|c|c|}
\hline Study & $\begin{array}{c}\text { Treatment } \\
\mathrm{n} / \mathrm{N}\end{array}$ & $\begin{array}{c}\text { Control } \\
n / N\end{array}$ & $\begin{array}{c}\text { Peto Odds Ratio } \\
95 \% \mathrm{Cl}\end{array}$ & $\begin{array}{c}\text { Peto Odds Ratio } \\
95 \% \mathrm{Cl}\end{array}$ \\
\hline \multicolumn{5}{|l|}{ 0I At I year } \\
\hline Andersson 1994 & $96 / 138$ & $46 / 71$ & $\square$ & $1.24[0.67,2.29]$ \\
\hline \multicolumn{5}{|l|}{02 At 2 years } \\
\hline Andersson 1994 & $104 / 138$ & $50 / 71$ & $\longrightarrow$ & $1.29[0.67,2.46]$ \\
\hline
\end{tabular}

\section{Comparison 05. Headaches}

\begin{tabular}{|c|c|c|c|c|c|}
\hline \multicolumn{6}{|c|}{ Comparison: 02 LNG-20 IUS vs. IUD $<=250 \mathrm{~mm} 2$} \\
\hline \multirow[t]{2}{*}{ Study } & Treatment & Control & \multirow{2}{*}{$\begin{array}{l}\text { Peto Odds Ratio } \\
\qquad 95 \% \mathrm{Cl}\end{array}$} & Weight & Peto Odds Ratio \\
\hline & $n / N$ & & & (\%) & $95 \% \mathrm{Cl}$ \\
\hline \multicolumn{6}{|l|}{ 0l At 5 years } \\
\hline Andersson 1994 & $12 / 736$ & $3 / 315$ & + & 100.0 & $1.62[0.53,4.92]$ \\
\hline Total $(95 \% \mathrm{Cl})$ & 736 & 315 & & 100.0 & $1.62[0.53,4.92]$ \\
\hline \multicolumn{6}{|c|}{ Total events: 12 (Treatment), 3 (Control) } \\
\hline \multicolumn{6}{|c|}{ Test for heterogeneity: not applicable } \\
\hline Test for overall effect & $p=0.4$ & & & & \\
\hline
\end{tabular}

Hormonally impregnated intrauterine systems (IUSs) versus other forms of reversible contraceptives as effective methods of preventing 3 I pregnancy

Copyright ( 2004 The Cochrane Collaboration. Published by John Wiley \& Sons, Ltd 


\section{Comparison 05. Breast tenderness}

Review: Hormonally impregnated intrauterine systems (IUSs) versus other forms of reversible contraceptives as effective methods of preventing pregnancy Comparison: 02 LNG-20 IUS vs. IUD $<=250 \mathrm{~mm} 2$

Outcome: 05 Breast tenderness

\begin{tabular}{|c|c|c|c|c|c|}
\hline Study & $\begin{array}{c}\text { Treatment } \\
\mathrm{n} / \mathrm{N}\end{array}$ & $\begin{array}{c}\text { Control } \\
\mathrm{n} / \mathrm{N}\end{array}$ & $\begin{array}{c}\text { Peto Odds Ratio } \\
95 \% \mathrm{Cl}\end{array}$ & $\begin{array}{c}\text { Weight } \\
(\%)\end{array}$ & $\begin{array}{c}\text { Peto Odds Ratio } \\
95 \% \mathrm{Cl}\end{array}$ \\
\hline \multicolumn{6}{|l|}{ 0l At 5 years } \\
\hline Andersson 1994 & $7 / 736$ & $2 / 315$ & & 100.0 & $1.45[0.35,6.07]$ \\
\hline Total $(95 \% \mathrm{Cl})$ & 736 & 315 & & 100.0 & $1.45[0.35,6.07]$ \\
\hline \multicolumn{6}{|c|}{ Total events: 7 (Treatment), 2 (Control) } \\
\hline \multicolumn{6}{|c|}{ Test for heterogeneity: not applicable } \\
\hline Test for overall effec & $p=0.6$ & & & & \\
\hline
\end{tabular}

$\begin{array}{lllllll}0.1 & 0.2 & 0.5 & 1 & 2 & 5 & 10\end{array}$

\section{Comparison 05. Acne}

Review: Hormonally impregnated intrauterine systems (IUSs) versus other forms of reversible contraceptives as effective methods of preventing pregnancy Comparison: 02 LNG-20 IUS vs. IUD $<=250 \mathrm{~mm} 2$

Outcome: 06 Acne

\begin{tabular}{|c|c|c|c|c|c|}
\hline Study & $\begin{array}{c}\text { Treatment } \\
n / N\end{array}$ & $\begin{array}{c}\text { Control } \\
\mathrm{n} / \mathrm{N}\end{array}$ & $\begin{array}{c}\text { Peto Odds Ratio } \\
95 \% \mathrm{Cl}\end{array}$ & $\begin{array}{c}\text { Weight } \\
(\%)\end{array}$ & $\begin{array}{c}\text { Peto Odds Ratio } \\
95 \% \mathrm{Cl}\end{array}$ \\
\hline \multicolumn{6}{|l|}{01 At 5 years } \\
\hline Andersson 1994 & $13 / 736$ & $1 / 315$ & & 100.0 & $3.01[0.95,9.51]$ \\
\hline Total $(95 \% \mathrm{Cl})$ & 736 & 315 & & 100.0 & $3.01[0.95,9.51]$ \\
\hline \multicolumn{6}{|c|}{ Total events: I3 (Treatment), I (Control) } \\
\hline \multicolumn{6}{|c|}{ Test for heterogeneity: not applicable } \\
\hline Test for overall effect & $p=0.06$ & & & & \\
\hline
\end{tabular}

$\begin{array}{llllllll}0.1 & 0.2 & 0.5 & 1 & 2 & 5 & 10\end{array}$ 


\section{Comparison 05. Nausea}

\begin{tabular}{|c|c|c|c|c|c|}
\hline \multicolumn{6}{|c|}{ Comparison: 02 LNG-20 IUS vs. IUD $<=250 \mathrm{~mm} 2$} \\
\hline \multicolumn{6}{|c|}{ Outcome: 07 Nausea } \\
\hline \multirow[t]{2}{*}{ Study } & Treatment & Control & Peto Odds Ratio & Weight & Peto Odds Ratio \\
\hline & $\mathrm{n} / \mathrm{N}$ & $\mathrm{n} / \mathrm{N}$ & $95 \% \mathrm{Cl}$ & $(\%)$ & $95 \% \mathrm{Cl}$ \\
\hline \multicolumn{6}{|l|}{ OI At 5 years } \\
\hline Andersson 1994 & $2 / 736$ & $0 / 315$ & & 100.0 & $4.18[0.20,86.13]$ \\
\hline Total $(95 \% \mathrm{Cl})$ & 736 & 315 & & 100.0 & $4.18[0.20,86.13]$ \\
\hline \multicolumn{6}{|c|}{ Total events: 2 (Treatment), 0 (Control) } \\
\hline \multicolumn{6}{|c|}{ Test for heterogeneity: not applicable } \\
\hline Test for overall effect & $p=0.4$ & & & & \\
\hline
\end{tabular}

\section{Comparison 05. Ovarian cysts}

\section{At 1 year}

Study

Andersson 1994

$12 / 18664$ women months vs. $4 / 9326$ women months

\section{Comparison 05. Expulsion}

\section{At 1 year}

Study

Andersson 1994 62/18664 women months vs. 32/9326 women months

Baveja 1989 Single decrement life table probabilities $(\mathrm{SE})=6.5(1.2)$ vs. CuT 220C 4.8 (1.0) and vs. CuT 200B 4.9 (1.0)

\section{At 2 years}

Study

Baveja 1989

Single decrement life table probabilities $(\mathrm{SE})=9.2$ (1.4) vs. CuT 220C 7.1 (1.2) and vs. CuT $200 \mathrm{~B} 7.7$ (1.3)

Luukkainen 1986 1/3083 women months vs. 9/2989 women montths

\section{At 5 years}

Study

Luukkainen 1986

2/5495 women months vs. 7/5176 women months

\section{Comparison 05. Ectopic pregnancy}

Hormonally impregnated intrauterine systems (IUSs) versus other forms of reversible contraceptives as effective methods of preventing 33 pregnancy

Copyright $\odot 2004$ The Cochrane Collaboration. Published by John Wiley \& Sons, Ltd 
At 1 year

Study

Andersson 1994

Luukkainen 1986

At 3 years

Study

Andersson 1994

At 5 years

Study

Andersson 1994
0/18664 women months vs. $1 / 9326$ women months

$1 / 1654$ women months vs. $0 / 1708$ women months

1/46200 women months vs. 5/23568 women months

1/67380 women months vs. 7/33312 women months

\section{Comparison 05. Pelvic inflammatory disease}

\section{At 1 year}

Study

Luukkainen 1986

0/1654 women months vs. 0/1708 women months

At 2 years

Study

Luukkainen 1986

0/3083 women months vs. 3/2989 women months

\section{Comparison 05. Hormonal reasons for discontinuation}

At 1 year

Study

Andersson 1994

54/18664 women months vs. 5/9326 women months

At 3 years

Study

Andersson 1994 110/46200 women months vs. 5/23568 women months

Baveja 1989 Total: 10/10589 women months vs. 27/24225 women months (vs. CuT220C 13/12076 women months and vs. CuT200B 14/12149 women months)

At 5 years

Study

Luukkainen 1986

$11 / 5495$ women months vs. $2 / 5176$ women months

Hormonally impregnated intrauterine systems (IUSs) versus other forms of reversible contraceptives as effective methods of preventing 34 pregnancy

Copyright $\odot 2004$ The Cochrane Collaboration. Published by John Wiley \& Sons, Ltd 


\section{Comparison 05 . Menstrual reasons for discontinuation: all}

At 1 year

Study

Andersson 1994

$153 / 18664$ women months vs. 65/9326 women months

Baveja 1989

Single decrement life table probabilities (SE) = 13.8 (1.7) vs. CuT 220C 6.0 (1.1) and vs. CuT 200B 5.7 (1.1)

At 2 years

Study

Baveja 1989

Single decrement life table probabilities $(\mathrm{SE})=21.9$ (2.1) vs. CuT 220C 9.9 (1.4) and vs. CuT 200B 8.8 (1.4)

At 3 years

Study

Baveja 1989 Single decrement life table probabilities $(\mathrm{SE})=27.9(2.3)$ vs. CuT 220C 15.4 (1.9) and vs. CuT 200B 14.6 (1.9)

At 5 year

Study

Luukkainen 1986

$26 / 5495$ women months vs. $21 / 5176$ women months

\section{Comparison 05. Menstrual reasons for discontinuation: bleeding \& pain}

\section{At 5 years}

Study

Luukkainen 1986

$11 / 5495$ women months vs. $21 / 5176$ women months

\section{Comparison 05. Menstrual reasons for discontinuation: amenorrhoea}

At 5 years

Study

Luukkainen 1986

$15 / 5495$ womenmonths vs. 0/5176 women months

\section{Comparison 05. Discontinuation due to adverse event}

At 1 year

Study

Andersson 1994

42/18664 women months vs. $21 / 9326$ women months

At 3 years

Study

Baveja 1989 Total: 2/10589 women months vs. 4/24225 women months (vs. CuT220C 0/12076 women months and vs. CuT200B $4 / 12149$ women months)

Hormonally impregnated intrauterine systems (IUSs) versus other forms of reversible contraceptives as effective methods of preventing 35 pregnancy

Copyright @ 2004 The Cochrane Collaboration. Published by John Wiley \& Sons, Ltd 
At 5 years

Study

Luukkainen 1986

5/5495 women months vs. $6 / 5176$ women months

\section{Comparison 05 . Discontinuation because planning pregnancy}

At 5 years

Study

Luukkainen 1986

10/5495 women months vs. $16 / 5176$ women months

\section{Comparison 05. Discontinuation for personal reasons}

\section{At 5 years}

Study

Luukkainen 1986

6/5495 women months vs. 3/5176 women months

\section{Comparison 05. Pregnancy}

\section{At 1 year}

Study

Wang 1992

$1 / 1157$ women months vs. $0 / 1187$ women months

At 2 years

Study

Wang 1992

$1 / 2171$ women months vs. $0 / 2218$ women months

At 3 years

Study

Wang 1992

1/3098 women months vs. 0/3093 women months

\section{Comparison 05. Continuation of method}

\section{At 1 year}

Study

Wang 1992

$81 / 1157$ women months vs. $93 / 1187$ women months

\section{Comparison 05. Expulsion}

Hormonally impregnated intrauterine systems (IUSs) versus other forms of reversible contraceptives as effective methods of preventing 36 pregnancy

Copyright $\odot 2004$ The Cochrane Collaboration. Published by John Wiley \& Sons, Ltd 
At 1 year

Study

Wang 1992

3/1157 women months vs. 0/1187 women months

\section{Comparison 05. Breast cancer}

At 1 year

Study

Wang 1992

0/1157 women months vs. 0/1187 women months

\section{Comparison 05. Ovarian cysts}

\section{At 1 year}

Study

Wang 1992

4/1157 women months vs. $1 / 1187$ women months

\section{Comparison 05. Spotting}

Review: Hormonally impregnated intrauterine systems (IUSs) versus other forms of reversible contraceptives as effective methods of preventing pregnancy Comparison: 03 LNG-20 IUS vs. Norplant-2

Outcome: 06 Spotting

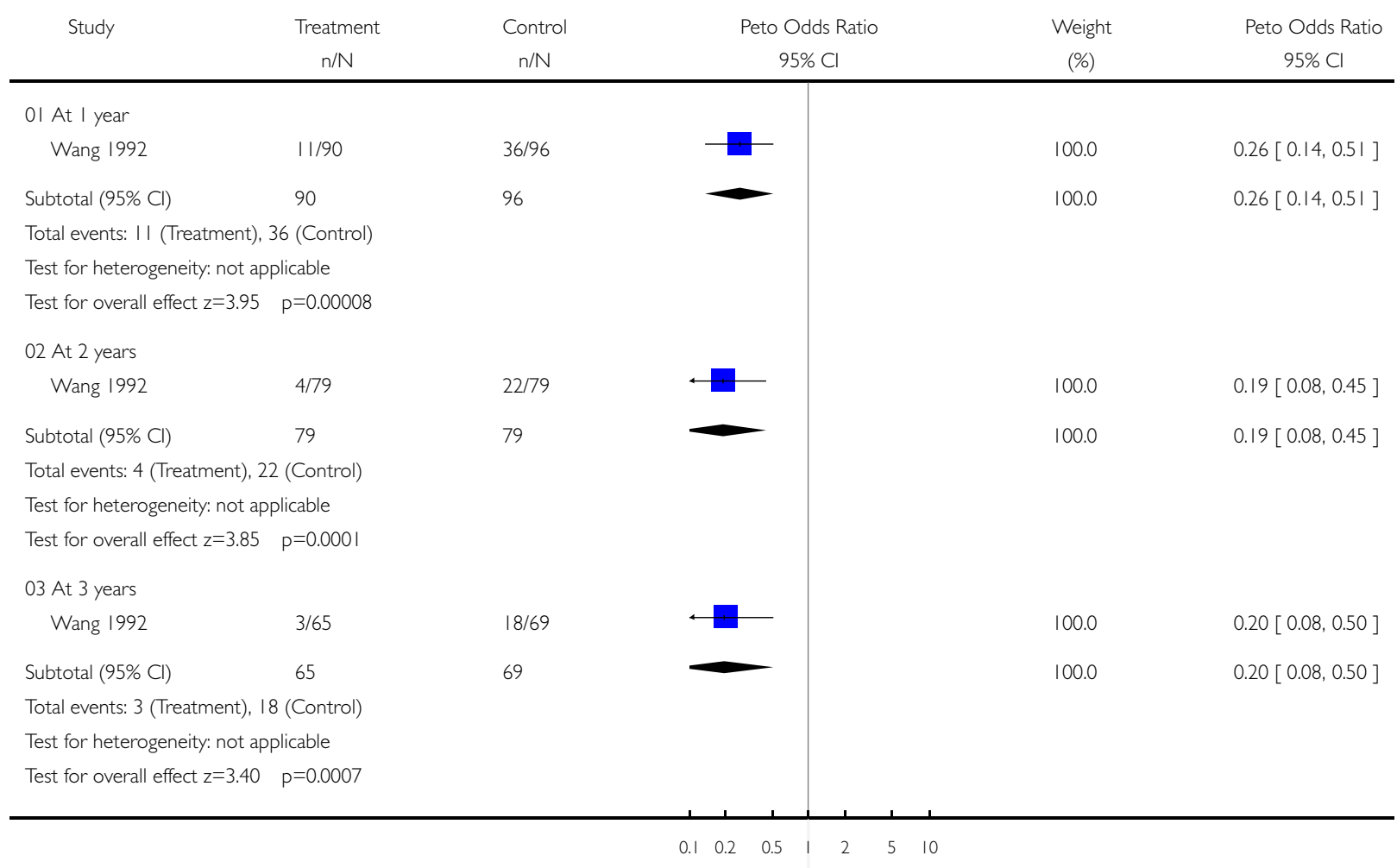

Hormonally impregnated intrauterine systems (IUSs) versus other forms of reversible contraceptives as effective methods of preventing 37 pregnancy

Copyright ( 2004 The Cochrane Collaboration. Published by John Wiley \& Sons, Ltd 


\section{Comparison 05. Oligomenorrhoea}

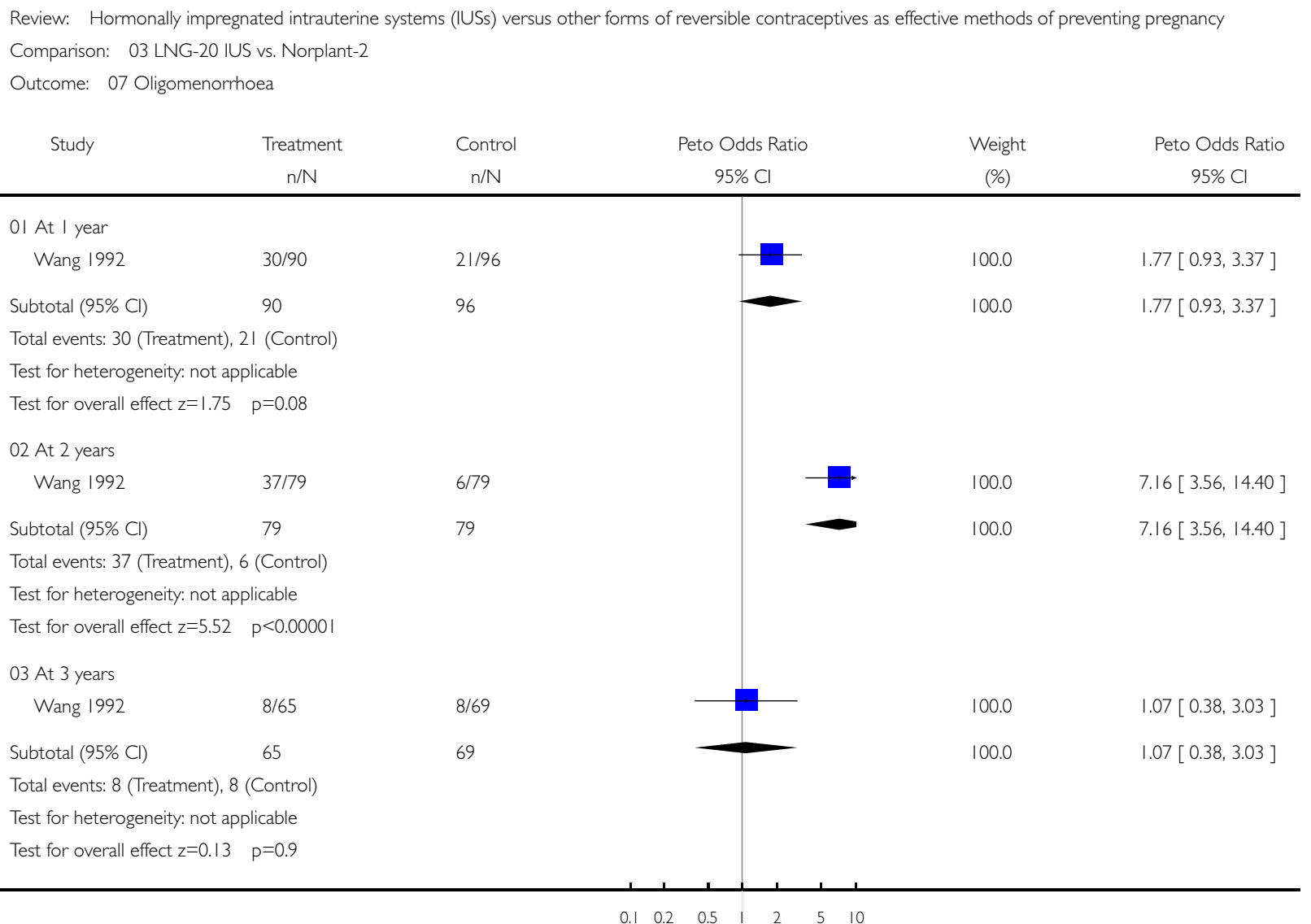




\section{Comparison 05. Amenorrhoea}

Review: Hormonally impregnated intrauterine systems (IUSs) versus other forms of reversible contraceptives as effective methods of preventing pregnancy Comparison: 03 LNG-20 IUS vs. Norplant-2

Outcome: 08 Amenorrhoea

Study $\quad$ Treatment $\quad$ Control $\quad$ Peto Odds Ratio $\quad$ Weight $\mathrm{n} / \mathrm{N} \quad \mathrm{n} / \mathrm{N} \quad 95 \% \mathrm{Cl}$ 95\% Cl

\begin{tabular}{|c|c|c|c|c|}
\hline \multicolumn{5}{|l|}{ 0I At I year } \\
\hline Wang 1992 & $17 / 90$ & $8 / 96$ & 100.0 & $2.47[1.06,5.72]$ \\
\hline Subtotal $(95 \% \mathrm{Cl})$ & 90 & 96 & 100.0 & $2.47[1.06,5.72]$ \\
\hline \multicolumn{5}{|c|}{ Total events: 17 (Treatment), 8 (Control) } \\
\hline \multicolumn{5}{|c|}{ Test for heterogeneity: not applicable } \\
\hline \multicolumn{5}{|c|}{ Test for overall effect $z=2.10 \quad p=0.04$} \\
\hline \multicolumn{5}{|l|}{02 At 2 years } \\
\hline Wang 1992 & $21 / 79$ & 0/79 & 100.0 & $9.89[3.96,24.72]$ \\
\hline Subtotal $(95 \% \mathrm{Cl})$ & 79 & 79 & 100.0 & $9.89[3.96,24.72]$ \\
\hline \multicolumn{5}{|c|}{ Total events: 2 I (Treatment), 0 (Control) } \\
\hline \multicolumn{5}{|c|}{ Test for heterogeneity: not applicable } \\
\hline \multicolumn{5}{|c|}{ Test for overall effect $z=4.91 \quad p<0.0000 \mid$} \\
\hline \multicolumn{5}{|l|}{03 At 3 years } \\
\hline Wang 1992 & $5 / 65$ & $2 / 69$ & 100.0 & $2.61[0.57,11.92]$ \\
\hline Subtotal $(95 \% \mathrm{Cl})$ & 65 & 69 & 100.0 & $2.61[0.57,11.92]$ \\
\hline \multicolumn{5}{|c|}{ Total events: 5 (Treatment), 2 (Control) } \\
\hline \multicolumn{5}{|c|}{ Test for heterogeneity: not applicable } \\
\hline Test for overall effe & $p=0.2$ & & & \\
\hline
\end{tabular}

$\begin{array}{lllllll}0.1 & 0.2 & 0.5 & 1 & 2 & 5 & 10\end{array}$ 


\section{Comparison 05. Prolonged bleeding}

\begin{tabular}{|c|c|c|c|c|c|}
\hline \multicolumn{2}{|c|}{$\begin{array}{l}\text { Comparison: } 03 \text { LNG-20 IUS vs. Norplant-2 } \\
\text { Outcome: } 09 \text { Prolonged bleeding }\end{array}$} & & & & \\
\hline \multirow[t]{2}{*}{ Study } & Treatment & Control & \multirow{2}{*}{$\begin{array}{c}\text { Peto Odds Ratio } \\
\quad 95 \% \mathrm{Cl}\end{array}$} & \multirow{2}{*}{$\begin{array}{l}\text { Weight } \\
(\%)\end{array}$} & \multirow{2}{*}{$\begin{array}{c}\text { Peto Odds Ratio } \\
95 \% \mathrm{Cl}\end{array}$} \\
\hline & $n / N$ & $\mathrm{n} / \mathrm{N}$ & & & \\
\hline \multicolumn{6}{|l|}{ OI At I year } \\
\hline Wang 1992 & $4 / 90$ & $33 / 96$ & & 100.0 & $0.15[0.08,0.32]$ \\
\hline Subtotal $(95 \% \mathrm{Cl})$ & 90 & 96 & & 100.0 & $0.15[0.08,0.32]$ \\
\hline \multicolumn{6}{|c|}{ Total events: 4 (Treatment), 33 (Control) } \\
\hline \multicolumn{6}{|c|}{ Test for heterogeneity: not applicable } \\
\hline \multicolumn{6}{|c|}{ Test for overall effect $z=5.10 \quad p<0.00001$} \\
\hline \multicolumn{6}{|l|}{02 At 2 years } \\
\hline Wang 1992 & $4 / 79$ & $24 / 79$ & & 100.0 & $0.18[0.08,0.40]$ \\
\hline Subtotal $(95 \% \mathrm{Cl})$ & 79 & 79 & & 100.0 & $0.18[0.08,0.40]$ \\
\hline \multicolumn{6}{|c|}{ Total events: 4 (Treatment), 24 (Control) } \\
\hline \multicolumn{6}{|c|}{ Test for heterogeneity: not applicable } \\
\hline \multicolumn{6}{|c|}{ Test for overall effect $z=4.15 \quad p=0.00003$} \\
\hline \multicolumn{6}{|l|}{03 At 3 years } \\
\hline Wang 1992 & $2 / 65$ & $14 / 69$ & & 100.0 & $0.20[0.07,0.56]$ \\
\hline Subtotal $(95 \% \mathrm{Cl})$ & 65 & 69 & & 100.0 & $0.20[0.07,0.56]$ \\
\hline \multicolumn{6}{|c|}{ Total events: 2 (Treatment), I4 (Control) } \\
\hline \multicolumn{6}{|c|}{ Test for heterogeneity: not applicable } \\
\hline Test for overall effe & $p=0.002$ & & & & \\
\hline
\end{tabular}

\section{Comparison 05. Pregnancy}

At 1 year

Study

Fylling 1979

7/1729 women months vs. 3/1483 women months

Larsen 1981

4/1996 women months vs. 4/1943 women months

\section{Comparison 05. Continuation of method}

\section{At 1 year}

Study

Larsen 1981
$150 / 1996$ women months vs. $142 / 1943$ women months Life table probabilities $(\mathrm{SE})=76.2(3.1)$ vs. 76 (3.2)

\section{Comparison 05. Expulsion}

Hormonally impregnated intrauterine systems (IUSs) versus other forms of reversible contraceptives as effective methods of preventing 40 pregnancy

Copyright $\odot 2004$ The Cochrane Collaboration. Published by John Wiley \& Sons, Ltd 
At 1 year

Study

Fylling 1979

2/1729 women months vs. $15 / 1483$ women months

\section{Comparison 05. Ectopic pregnancy}

At 1 year

Study

Fylling 1979

2/1729 women moths vs. 0/1483 women months

Larsen 1981

1/1996 women months vs. 0/1934 women months

\section{Comparison 05. Menstrual reasons for discontinuation: bleeding \& pain}

At 1 year

Study

Fylling 1979

$35 / 1729$ women months vs. $10 / 1483$ women months

\section{Comparison 05. Pregnancy}

At 1 year

Study

Newton 1979

3/3389 women months vs. $28 / 2953$ women months

\section{Comparison 05 . Continuation of method}

At 1 year

Study

Newton 1979

Life table probabilities (SE) $=74.4(2.4)$ vs. $65.8(2.8)$

\section{Comparison 05. Expulsion}

At 1 year

Study

Newton 1979

$25 / 3389$ women months vs. $23 / 2953$ women months

\section{Comparison 05. Ectopic pregnancy}

Hormonally impregnated intrauterine systems (IUSs) versus other forms of reversible contraceptives as effective methods of preventing 4 I pregnancy

Copyright ( 2004 The Cochrane Collaboration. Published by John Wiley \& Sons, Ltd 
At 1 year

Study

Newton 1979
0/3389 women months vs. 1/2953 women months
At 1 year

Study

Newton 1979

Study

Newton 1979

At 1 year
29/3389 women months vs. 22/2953 women months

\section{Comparison 05. Discontinuation because planning pregnancy}

10/3389 women months vs. 6/2953 women months

\section{Comparison 05. Discontinuation for personal reasons}

At 1 year

Study

Newton 1979
$8 / 3389$ women months vs. $15 / 2953$ women months 